\title{
A cor do Homem Nu: impasses de uma periferia branca diante do modernismo (Paraná, 1953)
}

The color of the Naked Man: impasses of a white peripheral region before Brazilian modernism (Paraná, Brazil, 1953)

https://doi.org/10.1590/1982-02672020v28d le7

\section{BENNO WARKEN ALVES'}

hitps://orcid.org/0000-0002-3175-4660

Universidade de São Paulo / São Paulo, SP, Brasil

\author{
1. Doutor em Sociologia da \\ Faculdade de Filosofia, \\ Letras e Ciências Humanas \\ da Universidade de São \\ Paulo (USP). E-mail: < \\ benno@alumni.usp.br>.
}

RESUMO: Em meados dos anos 1950, a construção de um monumento em Curitiba colocou a elite local diante de um impasse: como ser moderno, no Brasil do pós-guerra, sem deixar de ser branco? Concebido como parte das comemorações de cem anos de criação do Paraná, o monumento do centenário deveria dominar a praça do Centro Cívico - um conjunto administrativo moderno projetado para simbolizar a súbita transformação do Paraná em um dos estados mais ricos da federação. Os 21 gigantes de pedra que formariam o monumento, entretanto, acabaram sendo reduzidos a apenas um, o Homem Nu, obra dos escultores Erbo Stenzel e Humberto Cozzo. Neste artigo, analiso os sentidos relacionados à adaptação, construção e repercussão do monumento do Homem Nu, incluindo os atritos entre agentes locais e profissionais de vanguarda (e outros nem tanto) que trabalhavam no Rio de Janeiro. Procuro mostrar os esforços de uma fração da elite empenhada em atualizar sua região periférica seguindo os ditames de um movimento moderno desenvolvido no centro da vida cultural nacional. Contra a resistência de uma fração reacionária da elite, os modernos do Paraná conseguiram assegurar projetos arquitetônicos significativos, para em seguida recuar quando descobriram que ser moderno e brasileiro, nos anos 50, significava tornar-se menos branco.

PALAVRAS-CHAVE: Branquidade. Regionalismo. Modernismo. Arquitetura. Curitiba. Pós-guerra. 
ABSTRACT: In the mid-1950's, the construction of a monument in Curitiba, Paraná, led the local elite to an impasse: how to be modern, in postwar Brazil, without giving up being white? Conceived as part of the centenary commemorations of the state of Paraná, the monument should dominate the Civic Center plaza - an administrative complex planned to symbolize the sudden transformation of Paraná into one of the richer states in the federation. However, the 21 stone giants that would comprise the monument ended up reduced to only one, the Naked Man, made by sculptors Erbo Stenzel and Humberto Cozzo. In this article, I analyze the meanings associated with the adaptation, construction and repercussion of the Naked Man, including the conflicts between local agents and modernist professionals that worked in the Brazilian capital, Rio de Janeiro. I trace the efforts of an elite group focused in updating their region according to the standards set by a modern movement developed in the centers of the nation's cultural life. Facing resistance from a reactionary local elite group, the modern paranaenses were able to secure significant architectural projects, but only to retreat when they figured that being modern and Brazilian, in the postwar years, meant becoming less white.

KEY-WORDS: Whiteness. Regionalism. Modernism. Architecture. Curitiba/Paraná. Postwar. 
Em junho de 1955, a inauguração de uma estátua de oito metros no centro de Curitiba revoltou parte da elite da cidade. Estimulados por um articulista de pseudônimo Ariel, professores, artistas, senhoras católicas e magistrados juntaram-se numa campanha contrária às ideias encarnadas na estátua do Homem Nu. Ariel indignou-se, a princípio, com a indecência do "taradão de pedra", e também porque "[p]retendeu alguém explicar aquela monstruosidade como uma interpretação do homem do Paraná". Ora, escreveu, só podia estar "cego esse ARTIXTA [...] Porque a população do Paraná já tem no dolicocefalismo um denominador comum [...] Aquele tipo de Frankenstein não evoca o paranaense esbelto, com maior número de loiros que morenos". ${ }^{2}$ As reações inscreviam-se num contexto político em que atacar o Homem Nu era um modo de atacar o governador que idealizara o monumento. Contudo, para além do aspecto circunstancial, as críticas marcam o auge das tensões que acompanharam sua concepção e construção, tendo como cerne do problema a importação das ideias modernas para uma região periférica. Poderiam os paranaenses mandar trazer o moderno do Rio - um moderno formulado por artistas próximos do comunismo e fortemente influenciado pela visão nacional-popular - e ao mesmo tempo cultivar uma identidade diferencial baseada na branquidade?

Homem Nu foi construído como parte do Monumento ao Centenário: uma praça com diversas obras alusivas à comemoração, em dezembro de 1953, dos cem anos de criação do estado do Paraná. O centenário coincidiu com um rápido processo de desenvolvimento. Ao final da Segunda Guerra Mundial, o interior paranaense era a fronteira agrícola mais dinâmica do país. Sua colonização e a crescente exploração econômica, malgrado a degradação ambiental e a expulsão de indígenas e posseiros das terras que ocupavam, faziam crescer ano a ano a participação do estado nas exportações nacionais. As receitas do governo passaram por um período de aumento sem precedente, tornando o centenário uma oportunidade política única. $\bigcirc$ grupo no poder elaborou um extenso plano de obras para a capital e adotou a arquitetura como linguagem do progresso. Projetos antigos foram reformulados de acordo com as concepções mais avançadas, representadas pela então hegemônica "escola carioca" de Oscar Niemeyer e Lúcio Costa. Contra a resistência de uma fração reacionária da oligarquia - e contra o mercado imobiliário e o gosto médio dos curitibanos -, o grupo em torno do governador bancou a introdução definitiva da arquitetura moderna no Paraná por meio de obras monumentais. 
3. Cf. Guimarães (2001)

4. Weinstein (2006, p. 282).

5. Cf. Weinstein (2015).

Todavia, o evento que poderia ter marcado o entroncamento do periférico Paraná na corrente econômica e cultural do Brasil do pós-guerra expôs a incompatibilidade entre a modernidade formulada como brasileira e os anseios da elite paranaense. $\bigcirc$ mesmo governador que defendera a necessidade de importar a arquitetura moderna lutou como pôde para imprimir uma narrativa regionalista à principal das obras do centenário: queria construir, bem no meio do complexo administrativo projetado pelos discípulos de Lúcio Costa, um gigante de pedra simbolizando o Paraná a tomar a dianteira dos demais estados, a mostrar-thes o caminho. Em choque com os arquitetos do Rio, o governador não conseguiu impor sua vontade e o Homem Nu foi deslocado para fora do Centro Cívico. Somente após uma série de adaptações, por meio das quais os agentes locais buscaram preservar algo da intenção alegórica do governador, o Homem Nu tornou-se parte do Monumento ao Centenário.

O Homem Nu expressou uma tentativa de renegociar a relação simbólica entre o Paraná e o Brasil, em diálogo com os processos socioculturais que, desde os anos 1930, haviam forjado a identidade nacional. Enquanto agentes locais estavam interessados em conciliar o modernismo com suas próprias ideias sobre a região modernizar a região em seus próprios termos -, os profissionais do Rio mostravam-se pouco dispostos a aceitar o compromisso, defendendo concepções que, ao contrário, enquadravam o periférico Paraná na narrativa nacional formulada nos centros culturais do país. Para dificultar, um aspecto de sua identidade regional que os paranaenses mostraram ser inegociável, a branquidade, não se encaixava bem no Brasil dos modernos. Ainda que o ideal do embranquecimento permanecesse, naqueles anos, como o avesso que complementava o pacto da democracia racial, consolidara-se um modo de representar o povo brasileiro como trabalhador e mestiço. ${ }^{3}$

Se havia tensão entre região branca e nação mestiça, era porque nenhum prevalecera totalmente. Nem a centralização política promovida pelo Estado Novo havia conseguido suprimir os regionalismos, nem a hegemonia cultural da democracia racial eliminara, nos anos do pós-guerra, os discursos alternativos sobre raça e nação. ${ }^{4}$ O caso de São Paulo é exemplar: a guerra de 1932 contra o regime de Vargas revigorou o sentimento de superioridade regional e promoveu intensa reelaboração do regionalismo paulista, tendo como principais ingredientes, conforme mostrou Barbara Weinstein, ${ }^{5}$ o progresso e a branquidade. Como ela também notou, não se tratava, no caso dos paulistas, de substituir a narrativa nacional por uma narrativa regional concorrente, mas de disputar a narrativa nacional, deslocando-the o centro para São Paulo - como sugere o bandeirantismo - ou, então, colocando São Paulo no topo, à frente, na liderança do Brasil - a exemplo da imagem da "locomotiva". Discursos como esses "estavam intimamente 
conectados com identidades regionais que persistiram além dos anos Vargas", ${ }^{6}$ tornando-se, no caso de São Paulo, fundamento e expressão ideológica de sua emergência como potência nacional ao longo do século XX.

No Paraná, ao contrário, foi a redemocratização, após período centralista e autoritário, que permitiu a renovação do regionalismo. Vargas perpetrou uma das maiores humilhações à elite política paranaense: a criação do Território Federal do Iguaçu (incorporando toda a porção oeste do estado), que existiu sob controle direto do governo central entre 1943 e 1946. Enquanto a elite paulista, por seu poder político e econômico, conseguiu preservar margem de autonomia frente ao governo central, no Paraná só a queda de Vargas (com a retomada do controle sobre o Território do Iguaçu, na Constituição de 1946) possibilitou à oligarquia da Primeira República voltar a disputar o poder. E voltar a disputar a relação de sua região com a nação. Sua adesão apenas parcial ao modernismo, contudo, conduziu a elite paranaense a um impasse ideológico: como ser moderno sem ser exatamente brasileiro?

\section{OBRAS CONTRA O ATRASO}

"Senhor governador" - escreveu, em janeiro de 1955, o chefe da Comissão Especial de Obras do Centenário (Ceoc) - "vossa excelência adiantou, em termos de século, o relógio que marca a evolução social, cultural, e até econômica, do Paraná". Seria impossível, prosseguia a carta, "negar o tremendo estímulo urbanístico e cultural que essas obras trouxeram à nossa capital [...] A verdade é que [elas] anteciparam a maturidade da nossa civilização [...]", além de contribuir para um "ambiente social de elevado conforto físico, mental e espiritual". 7 engenheiro-chefe da Ceoc, Ivo Arzua Pereira, ${ }^{8}$ referia-se ao ambicioso programa de construção colocado em marcha pelo governador Bento Munhoz da Rocha Neto ${ }^{9}$ nos primeiros anos da década de 1950. A grande justificativa para as obras era comemorar, em dezembro de 1953, os cem anos de criação do estado do Paraná. Entre 1951 e 1954, período em que Rocha esteve à frente do governo estadual, a autarquia investiu 435 milhões de cruzeiros, quase $6 \%$ de toda a receita do estado no período. ${ }^{10}$ A escritora Rachel de Queiroz, de passagem por Curitiba em 1952, reparou que "[s]ó se ouve falar em milhões, em arranha-céus; os grandes prédios brotam por toda parte e nos bairros residenciais as casas de rico se multiplicam"." A Ceoc deixou impactos profundos na capital, mas também nos debates sobre qual seria o lugar do Paraná, até então um estado periférico, no Brasil moderno que emergia com o fim da Segunda Guerra.
6. Id. (2006, p. 282).

7. Pereira (1955a).

8. Ivo Arzua Pereira (19252012) era engenheiro formado na Universidade do Paraná (1948). Presidiu a Comissão Especial de Obras do Centenário de 28 de junho de 1954 a 4 de abril de 1955. Antes, em 1953, havia sido superintendente da administração do Porto de Paranaguá, já no governo Munhoz da Rocha. Foi prefeito de Curitiba entre 1963 e 1967 e ministro da Agricultura entre 1967 e 1969.

9. Bento Munhoz da Rocha Neto (1905-1973), engenheiro formado na Universidade do Paraná (1927), foi governador do estado entre 1951 e 1955 , ministro da Agricultura em 1955 e deputado constituinte em 1946, deputado federal de 1946 a 1951 e novamente de 1959 a 1963.

10. Pereira (1955c).

11. Paraná e Santa Catarina (1952). 
12. Prefeitura Municipal de Curitiba (1943).

13. Sobre a atuação de Agache no Rio de Janeiro, com ênfase na resistência a seu urbanismo racional, ver o livro de Brodwin Fischer, em especial o capítulo "The city of hills and swamps" (Fischer, 2008, p. 38-49).

14. Cf. Galani (2015).

15. A "burguesia do mate" criou numerosas instituições culturais em Curitiba desde a emancipação política, e sobretudo entre as últimas décadas do século XIX e as primeiras do século $\mathrm{XX}$ (Bega, 2013, p. 96). O sentido essencialmente "burguês" da dominação dessa elite estaria relacionado com a disseminação precoce do trabalho "livre" e de relações de mercado - decorrente das especificidades da produção do mate - e com um tipo particular de moralismo, voltado para o controle social e a produtividade $\mathrm{cf}$. (Pereira, 1996).

16. Artigo publicado por Fernando Correa de Azevedo no jornal Gazeta do Povo em 16 de janeiro de 1949, reproduzido em Dudeque (2001, p. 415-418).
Porém, várias das obras colocadas em execução para o centenário precederam a criação da $\mathrm{Ceoc}$, tendo sido concebidas por outras razões, independentemente das comemorações de 1953. O Centro Cívico é o melhor exemplo. Embora fosse o principal entre os projetos, fora previsto dez anos antes, no primeiro plano urbanístico de Curitiba, o Plano Agache. Encomendado pela prefeitura e elaborado pelo urbanista francês Alfred Agache em 1941, o plano incluía, entre outras intervenções, a construção de uma praça concentrando os prédios dos três poderes estaduais ${ }^{12}$ e refletia a intenção, por parte da elite brasileira, de modernizar o país - de acordo com a "nova ciência do urbanismo" que Agache bem representava - por meio de grandes reformas urbanas. ${ }^{13}$ Alguns aspectos do plano foram implementados, mas o complexo ainda não havia saído do papel às vésperas do centenário. $\bigcirc$ novo teatro do estado encontrava-se em situação semelhante. $\bigcirc$ governo estadual promoveu um concurso de anteprojetos e escolheu o vencedor em 1948, mas a obra tampouco foi iniciada a tempo. Para a biblioteca pública, fora realizado concurso em 1946, sem continuidade. ${ }^{14}$ Num de seus primeiros pronunciamentos como governador, no início de 1951, Munhoz da Rocha anunciou que construiria a nova biblioteca pública. Seria a prioridade de sua gestão para comemorar o centenário, mas não fazia parte, ainda, de nenhum plano mais amplo de obras, consistindo em iniciativa isolada.

Obras como essas consumiram empenho, mobilizaram agentes públicos, profissionais e a imprensa, mas às portas do centenário ainda não haviam saído do papel, e podem ser compreendidas como fruto das ambições, muitas vezes desencontradas, da elite local. Quando a prefeitura de Curitiba contratou a firma carioca com a qual Agache trabalhava, o urbanista francês já tinha assinado planos de intervenção em algumas das principais capitais do país. Entre o final dos anos 1920 e início dos 1930, trabalhara no Recife, no Rio de Janeiro e em Porto Alegre. Contratar Agache significava vislumbrar para Curitiba um futuro europeizado, equivalente à perspectiva urbana dessas outras cidades, o que era no mínimo ousado em 1941. As elevadas pretensões da elite curitibana remontam a outras iniciativas culturais de vanguarda, como a criação do Museu Paranaense em 1867, um dos primeiro museus do país, e a fundação da Universidade do Paraná em $1912 .{ }^{15}$ Já o teatro e a biblioteca, iniciativas surgidas no pós-Segunda Guerra, refletem certa percepção de que o estado desenvolvia-se rapidamente e exigia a criação, por iniciativa pública, de instituições típicas da vida urbana de uma grande capital. Assim, um dos projetos em disputa para o novo teatro, no concurso de 1948, foi defendido como o mais apropriado para dotar a cidade de "um monumento digno do seu progresso". ${ }^{16}$ No mesmo sentido, ao anunciar a construção da biblioteca no início de 1951, o governador não deixou de 
expressar "constrangimento" por ter "o Paraná regredido nesse fundamental setor cultural"17 - ao contrário do que exigiam os avanços em outras áreas.

Embora a arrecadação do estado tenha melhorado ano a ano com o fim da Segunda Guerra, em virtude da produção e preço crescentes do café, ${ }^{18}$ o primeiro governador do período democrático não mostrou grande interesse em executar esses projetos. Moysés Lupion ${ }^{19}$ era um rico empresário ligado à exploração de terras e madeira nas áreas de colonização do interior do estado. Empreendedor político agressivo, não compartilhava do interesse da elite curitibana em forjar uma civilização local por meio de iniciativas culturais. $\bigcirc$ adversário que Lupion derrotou nas eleições de 1947 teve melhor sorte em 1950, quando venceu Ângelo Lopes, o candidato a sucessor do lupionismo. Bento Munhoz da Rocha Neto era exatamente o oposto de Lupion: nascido na cidade mais antiga do estado, a litorânea Paranaguá, era herdeiro da oligarquia da Primeira República, culto, professor da Universidade do Paraná, onde se formara em engenharia civil, mas dava aulas de sociologia e história, e dispunha de boas ligações familiares em Curitiba. Munhoz da Rocha retomava para a oligarquia local o poder que havia ficado sob intervenção de Vargas entre 1930 e 1945 e, até 1950, sob forte influência do campo varguista e de elites surgidas do desenvolvimento econômico do interior. Assim que assumiu o governo, nos primeiros meses de 1951, mobilizou o poder público para realizar as iniciativas culturais da elite paranaense represadas ao longo das últimas décadas.

$\bigcirc$ centenário foi uma justificativa conveniente. Ainda no início de 1951, Munhoz da Rocha apresentou a intenção de construir a nova biblioteca pública como principal contribuição do governo às comemorações. A biblioteca, um projeto isolado, possivelmente ficou a cargo do secretário estadual de Educação e Cultura lque era também presidente da Comissão Central de Festejos do Centenário, criada em maio de 1951). ${ }^{20}$ Ao longo do semestre, porém, as ambições para o centenário cresceram. Em agosto, o governador instituiu a Ceoc. A lei que a criou determinava que o plano de obras a ser elaborado fosse constituído por "Palácio do Governo, Palácio da Justiça, Palácio da Assembleia Legislativa, Edifícios das Secretarias" (juntos, formavam o Centro Cívico), além de "Biblioteca Pública, Teatro Guaíra e Monumento do Centenário". ${ }^{21}$ A biblioteca, portanto, foi o embrião de um plano mais abrangente e acabou incorporada a ele.

A Ceoc reunia, sob administração e orçamento centralizados, diversos projetos concebidos em diferentes momentos, por diferentes agentes e com objetivos distintos. Embora as obras principais, sobretudo o novo centro administrativo, concentrassem as atenções, o caráter disperso da comissão tornou-se mais claro conforme, com o tempo, mais obras acabaram sob sua responsabilidade. ${ }^{22} \bigcirc$ alto orçamento, o pessoal e as
17. Mensagem apresentada à... (1951, p. 115).

18. Entre 1945 e 1951 , isto é, em apenas seis anos, a receita do governo estadual multiplicou-se por seis, em virtude do imposto sobre exportação de café. Até o final da década de 1950, a importância relativa do Paraná no produto interno nacional passaria de $3 \%$ para 6\% (Padis, 1971, p. 49; idem, 1981, p. 119, 142).

19 Moysés Lupion de Troya (1908-1991) foi governador do Paraná por dois mandatos, de 1947 a 1951 e de 1956 a 1961 . Foi senador de 1955 a 1956 e deputado federal de 1963 a 1964. Teve o mandato e os direitos políticos cassados com base no Ato Institucional $\mathrm{n}^{\circ} \quad 1 \mathrm{da}$ ditadura militar.

20. Decreto $\mathrm{n}^{\circ} 1.084,11 \mathrm{de}$ maio de 1951.

21. Lei $n^{\circ} 674$ de 29 de agosto de 1951.

22. Um balanço de abril de 1955 relatava que, em acréscimo à lista inicial, a Ceoc construíra integralmente ou realizara obras as mais díspares, incluindo: Grupo Escolar Tiradentes, Instituto de Biologia e Pesquisas Tecnológicas, Instituto de Engenharia, Caixa de Habitação do Estado do Paraná, um Corpo de Bombeiros, Centro de Letras, União Paranaense de Estudantes, Palácio São Francisco (sede do governo estadual entre 1938 e 1953) e Instituto Histórico e Geográfico do Paraná; além de ter construído um estande de tiro e canalizado um dos rios que cruzam a cidade. Pereira (1955b, anexo). 
23. O primeiro engenheirochefe da Ceoc, Elato Silva, parece ter sido receptivo a esse tipo de demanda, pois as repassava para o governador. Silva (19521953).

24. Lei $\mathrm{n}^{\circ} 674$ de 29 de agosto de 1951.

25. Batistella (2017, p. 21).

26. Nasser (1956, p. 52-60).

27. Ipardes (1989, p. 23).

28. C.E.O.C., uma sigla... (1953, p. 26).

29. O monumental Centro... (1953, p. 192). máquinas da Ceoc a tornavam um conveniente guarda-chuva para obras públicas e privadas. A construção de um estande de tiro parece ter sido solicitada pelo Club Paranaense de Caça e Tiro. A Santa Casa de Misericórdia de Curitiba chegou a solicitar à Ceoc a realização a preço de custo da estrutura de concreto armado para seu novo hospital psiquiátrico. ${ }^{23}$ Enquanto alguns viam prosperar projetos que consideravam importantes para a "civilização" do Paraná, outros faziam bons negócios.

As obras, inevitavelmente, se tornaram foco da disputa política no estado. Os termos da disputa ilustram o contraste ideológico entre as intenções que levaram, sob Lupion, ao represamento dos projetos e, sob Munhoz da Rocha, à decisão de executar o vasto programa de obras. A Ceoc nasceu com orçamento de 100 milhões de cruzeiros. Em 1955, já tinha gasto mais de 400 milhões, e várias das principais obras - incluindo o Centro Cívico e o Teatro Guaíra estavam inconclusas. Como parâmetro, quatro meses antes de sua criação, o decreto que instituíra a Comissão Central de Festejos, encarregada de organizar todas as demais atividades do centenário, atribuíra-the orçamento inicial de apenas 400 mil cruzeiros. ${ }^{24}$ Compreende-se, assim, a campanha empreendida pelos órgãos de imprensa vinculados a Moysés Lupion. Munhoz da Rocha era retratado em charges como um perdulário elitista e delirante, empenhado em construir pirâmides modernas, enquanto necessidades básicas como estradas, energia elétrica e transporte público eram negligenciadas. ${ }^{25}$ Essa narrativa crítica se espalhou pelo Brasil, mais tarde, por meio de uma reportagem do famoso jornalista David Nasser para a revista $O$ Cruzeiro, que incluía fotografias das obras tomadas pela capoeira. ${ }^{26}$ Além da oposição entre palácios e obras úteis, vingou por aqueles anos a oposição entre Curitiba e interior: corria a tirada segundo a qual o governador fora no máximo um bom prefeito de Curitiba. ${ }^{27}$

O principal jornal governista, por outro lado, retratava o governador como um visionário e as obras como signo do progresso. Nas páginas d' $O$ Estado do Paraná, o Centro Cívico era "o monumento da grandeza de nossa terra e da convicção em seu porvir" e a biblioteca e o teatro, "as sedes culturais que faltavam" ao estado. ${ }^{28}$ Era $\circ$ programa do grupo que cercava $\circ$ governador. Para $\circ$ engenheiro-chefe da Ceoc, que conhecia bem a dimensão dos gastos, as obras respondiam às "necessidades e possibilidades futuras do Paraná, como estado que se destina, sem dúvida alguma, a liderar, muito logo, a economia nacional", sendo "o monumental Centro Cívico", em especial, "signo da avançada mentalidade de um governo e de um povo", conforme dizia uma publicação oficial. ${ }^{29}$ Diversas pessoas destacadas na vida cultural da cidade e mesmo de expressão nacional sintonizavam-se com esse pensamento. Quando, em 1954, o grande auditório do teatro foi aberto, ainda em obras, para uma apresentação especial da Orquestra 
Sinfônica Brasileira (sua primeira em Curitiba), seu maestro, Eleazar de Carvalho, teria chamado o Teatro Guaíra de "obra monumental que revela as preocupações do governador Munhoz da Rocha em construir no Paraná edifícios que sejam a tradução fiel do bom gosto e progresso cultural dos paranaenses". ${ }^{30}$

Embora a modernização do Paraná fosse central na retórica política tanto de Lupion quanto de Munhoz da Rocha, ${ }^{31}$ os dois governadores e os grupos que representavam tinham visões distintas sobre como construir um estado moderno. No centenário, prevaleceria a visão da oligarquia tradicional, mais especificamente de uma fração liderada por Munhoz da Rocha. Essa fração inclinava-se favoravelmente para o movimento modernista, fazendo convergir modernização e modernismo, mas rejeitava a concepção mestiça de brasilidade e de povo brasileiro que, no pós-guerra, tornara-se hegemônica no bojo desse movimento.

\section{MODERNIDADE, AINDA QUE TARDIA}

Os principais planos encampados pela Ceoc, contudo, tinham envelhecido entre sua concepção, na década de 1940, e a decisão de construílos, no começo dos anos 1950. O período viu a consolidação da arquitetura moderna no Brasil - o prédio do Ministério da Educação e Saúde (MES) foi inaugurado no Rio de Janeiro em $1943^{32}$ - bem como a consagração mundial da arquitetura brasileira, que passou a representar cada vez mais a "imagem do país". ${ }^{33}$ Ainda em 1943, fora realizada a exposição Brazil Builds no Museu de Arte Moderna de Nova York ${ }^{34}$ e na mesma cidade estava em construção, desde 1948, a sede das Nações Unidas, com projeto de Oscar Niemeyer e Le Corbusier. $\bigcirc$ grupo no poder percebeu que a arquitetura moderna potencializaria a relevância de seus planos para Curitiba. Mesmo enfrentando resistências, Munhoz da Rocha acabaria por patrocinar a atualização dos projetos antigos de acordo com essa visão.

Se nos centros da produção cultural brasileira o movimento moderno, em suas várias frentes, já se tornara dominante no imediato pós-guerra, no Paraná ele ainda era marginal. Na literatura, houvera certos impulsos nos anos 1920 e 1930 (destacaram-se os futuristas), mas muitos dos seus entusiastas deixaram de produzir ou foram viver no Rio de Janeiro, ficando prejudicado o desenvolvimento de uma corrente local. ${ }^{35}$ Em 1939, surgiu em Curitiba $\bigcirc$ Livro, que "no início da década de 1940 já era uma revista bastante madura nos seus posicionamentos modernos", tendo assumido a "tomada de partido pelo paradigma moderno e a referência ao modernismo central". ${ }^{36}$ Entre 1946 e 1948, uma nova geração de escritores,
30. Teixeira (1992, p. 82).

31. Ipardes (1989, p. 23).

32. Como marcos do processo de conquista de posição dominante pelos arquitetos modernos, Lauro Cavalcanti (2006, p. 10) menciona, além da "construção de monumentos estatais para o Estado Novo", outras duas frentes: "a instalação de um serviço de patrimônio responsável pela constituição de um capital simbólico nacional [...] e [...] a proposição de projetos de moradias econômicas".

33. Simioni (2013, p. 7).

34. Cf. Deckker (2001).

35. Oliveira (2005, p. 55-56).

36. Romanovski (2016, p. 204). 
37. Ibid.

38. Romanovski (2014, p. 9).

39. Ibid. (p. 10).

40. Lazzarotto ilustrou o folheto promocional

"International Coffee Exbibition - Exposição Internacional do Café", produzido pela Impressora Paranaense sob encomenda da Comissão de Comemorações do Centenário do Paraná, e a primeira edição do livro de Temístocles Linhares mencionado a seguir.

41. Romanovski (2014, p. 78).

42. Ibid. (p. 107).

43. Ibid. (p. 109). críticos literários e artistas organizou-se em torno à revista Joaquim, dedicada às artes e à cultura. ${ }^{37}$ Seus editores combatiam o "atraso da vida cultural paranaense", creditado à mediocridade e ao provincianismo dos intelectuais. ${ }^{38}$ Identificavam esses defeitos sobretudo no paranismo, movimento surgido no final da Primeira República que buscou criar uma identidade local por meio da historiografia, da literatura e das artes. $\bigcirc$ "conteúdo da renovação" buscado pelo grupo de Joaquim era, novamente, a "adesão aos princípios modernos vigentes nos centros culturais brasileiros". ${ }^{39}$ Ao questionar o lugar da "província" diante do país, assumiam a missão de entroncar um Paraná provinciano no Brasil moderno.

Alguns intelectuais que formavam o grupo começaram a se tornar conhecidos à época do centenário e envolveram-se direta ou indiretamente com as comemorações. Poty Lazzarotto, ilustrador e artista plástico, viria a produzir um painel de azulejos para - Monumento do Centenário e ilustrar diversas publicações; ${ }^{40}$ e os críticos Temístocles Linhares e Wilson Martins, também colaboradores da revista, escreveriam, respectivamente, Paraná Vivo (1953) e Um Brasil Diferente (1955), ensaios sociológicos que reinterpretavam o Paraná em rápido processo de desenvolvimento à luz de aspectos de sua história - longe, contudo, das convenções ufanistas do paranismo. Um contraste relevante produzido por esses intelectuais modernos era a valorização das pessoas, das situações e dos sentimentos comuns, em oposição à profundidade afetada e culto às "grandes personalidades". O próprio nome da revista, Joaquim, cuja dedicatória rezava "em homenagem a todos os Joaquins do Brasil", ${ }^{41}$ sugeria o comum, o banal; e os dois ensaios sobre o Paraná exercitavam o pensamento sociológico que procura explicar as grandes transformações mais pela mudança de mentalidade e atitude das pessoas comuns, das massas, do que pelos grandes acontecimentos ou ações heroicas.

Embora se afastasse das críticas mais provocativas ao paranismo, o governador Munhoz da Rocha tinha sido próximo do grupo da revista, sobretudo de Temístocles Linhares. ${ }^{42}$ Pouco antes do surgimento da revista, nos anos finais do Estado Novo, os dois costumavam juntar-se a outros boêmios que, saindo à noite das faculdades e redações dos jornais, formavam a "patrulha da madrugada" pelas ruas de Curitiba. Logo mais, em 1947, quando era deputado federal, Munhoz da Rocha chegou a publicar um texto em Joaquim. ${ }^{43}$ Wilson Martins, o outro crítico literário que colaborava com a revista, dedicaria seu livro de 1955 ao governador. No centenário, portanto, devido a ligações pessoais ou a afinidades ideológicas, os antigos críticos do establishment cultural tinham canais abertos com o poder.

Na arquitetura, as ideias modernas também tinham ocupado posição marginal até aquele momento. Assim como nas letras, houvera na Curitiba do entreguerras iniciativas mais ou menos isoladas, como as do arquiteto Frederico Kirchgässner, que projetou sua própria residência de vanguarda em 1930 e 
trabalhava na prefeitura municipal. Desenvolveu suas ideias diretamente a partir das correntes europeias, não chegando a formar um grupo ou escola, e não conheceu grande repercussão. ${ }^{44}$ Mais tarde, diversos profissionais formados em engenharia na Universidade do Paraná, como Rubens Meister, Ayrton Cornelsen e Romeu Paulo da Costa passaram a desenvolver projetos incorporando ideias modernas, mas o panorama profissional em Curitiba era desfavorável. Como disse outro desses engenheiros, Elgson Ribeiro Gomes, que passou a década de 1950 inteira trabalhando em São Paulo, "em 1945 não era fácil ser arquiteto em Curitiba, por dois motivos simples: não existir faculdade de arquitetura nem ateliê de arquiteto propriamente dito, onde se pudesse ingressar para aprender e trabalhar" ${ }^{45}$

Em Londrina, no norte do estado, sob forte influência paulista, dois projetos modernos do curitibano João Batista Vilanova Artigas, professor da Universidade de São Paulo, tinham sido construídos entre o fim dos anos 1940 e o início dos 1950: a estação rodoviária e o Cine Ouro Verde. Não havia, contudo, uma "escola" paranaense ou curitibana de arquitetura. Nem no sentido formal, já que o primeiro curso de Arquitetura e Urbanismo da Universidade Federal do Paraná seria criado apenas em 1962, nem no sentido de corrente intelectual - a escola que ficaria conhecida como "grupo do Paraná", ligada ao curso da Universidade Federal e sob influência dos brutalistas de São Paulo, também se desenvolveria apenas nos anos 1960.46 Assim, no limite, ao longo dos anos 1950, o que houve de arquitetura moderna em Curitiba foram "exemplos isolados criados por arquitetos do Rio de Janeiro ou [...] aproximações realizadas por engenheiros locais". ${ }^{47}$

Nos grandes centros, entre o final dos anos 1930 e o início dos 1940, "os arquitetos modernos disputavam com os adeptos das correntes neocolonial e acadêmica o privilégio de serem escolhidos pelo governo para efetuar as construções de seus ministérios e repartições". 48 Em Curitiba, a "unanimidade modernista" demoraria bem mais para se estabelecer. No final dos anos 1940, predominava ainda nos círculos mais cultos da cidade a preferência pela arquitetura tradicional.

concurso de anteprojetos para o novo teatro é ilustrativo. Foi promovido em 1948 ainda pelo governo de Lupion. Concorreram 17 anteprojetos. ${ }^{49} \bigcirc$ resultado acendeu uma polêmica com foco nas ideias modernas. Fernando Corrêa de Azevedo, diretor da Escola de Música e Belas Artes do Paraná e membro da banca do concurso, insurgiu-se em janeiro de 1949 contra as escolhas para primeiro e segundo lugares, demasiado conservadoras. Em sua opinião, teriam sido "as perspectivas, o estilo e mesmo a fachada" - isto é, o "elemento subjetivo" - que tiraram "o primeiro lugar ao ante-projeto que [...] merecia-o mais que qualquer outro". 50 No jornal curitibano
44. Gnoato (1997, p. 67).

45. Pacheco (2010, p. 29).

46. Ibid. (p. 66).

47. Ibid. (p. 67).

48. Cavalcanti (2006, p. 13).

49. Cf. Millarch (1990).

50. O artigo, intitulado "O Teatro Oficial do Estado”, foi publicado na Gazeta do Povo, em 16 de janeiro de 1949, e reproduzido em Dudeque (2001, p. 415-418). 
51. Batistella (2016, p. 160).

52. Pacheco (2010, p. 20).

53. E, num comentário espirituoso que ilustra a divisão estético-política que animava a crítica de Azevedo, "não se compreende mais que um cidadão para dizer: eu te amo, precise do acompanhamento de 120 professores de orquestra e gaste dez minutos nessas três palavras". (Azevedo apud Dudeque, 2001, p. 418).

54. Como defende Cavalcanti (2006, p. 10).

55. Azevedo apud Dudeque (2001, p. 417).

56. Ibid.

57. Azevedo apud Dudeque (2001, p. 416).

58. Dudeque (2001, p. 415).

59. Ibid.
Gazeta do Povo - à época, vinculado ao governador Lupion ${ }^{51}$-, o crítico caracterizou o primeiro lugar como "absolutamente banal", "moderno moderado, sóbrio, que não se desligou ainda do passado para se arrojar na independência de uma forma mais pura", enfim, uma "[m]istura de estilos" - ainda que tivesse "um bom estudo de interior". A proposta assemelhava-se ao edifício do Colégio Estadual do Paraná, recém-construído de acordo com o conceito austero da arquitetura do Estado Novo. Quanto ao segundo lugar, afirmava, "o autor não soube aproveitar o que a técnica moderna oferece de vantajoso na construção interna de um teatro", mesmo que nada o impedisse de apresentar "um interior dotado de todo o conforto e técnica modernos e um exterior de qualquer escola clássica" - a proposta neoclássica, com colunas e frontão grego, fora assinada pelo arquiteto que também havia repaginado em linhas neoclássicas o então edifício central, em estilo eclético, da Universidade do Paraná. ${ }^{52}$

Seu projeto preferido era o terceiro lugar, assinado por um dos poucos profissionais que incorporavam ideias modernas em Curitiba, Rubens Meister. Azevedo destacou as qualidades técnicas da proposta, em comparação com as outras, mas os principais argumentos centravam-se numa visão de modernidade. "Não se pode hoje em dia pensar em teatro para ópera", respondia aos argumentos de outro membro da banca, não só porque "qualquer grande ópera se leva tão bem num teatro antigo quanto num moderno", mas também porque "ninguém hoje escreve mais óperas". ${ }^{53}$ Sua visão de modernidade passava por um dos debates centrais para a consagração do movimento, a patrimonialização dos monumentos coloniais e modernos:54 "qualquer construção feita hoje em estilo de épocas anteriores não passará de imitação sem autenticidade". ${ }^{55} \mathrm{Em}$ seguida, elogiava o Serviço do Patrimônio Histórico e Artístico e Nacional (Sphan) por ter feito "erigir em Vila Rica um hotel da mais moderna arquitetura [de Niemeyer] para salvaguardar a intangibilidade dos velhos e legítimos prédios coloniais". ${ }^{56}$ Por isso, um teatro do tempo presente deveria ser construído de acordo com as concepções do tempo presente, e não como imitação de estilos do passado. Sua característica mais destacada, "um arco, bonito ou feio, pouco importa, [é] da época em que foi construído".57 A contemporaneidade das formas começava a se descolar da imitação de estilos consagrados, abrindo margem para a adoção de um modernismo que, se era internacional, não deixava de ser profundamente brasileiro, pois desabrochava no Brasil. Os argumentos de Azevedo, em 1949, teriam sido fundamentais para que o governador, em 1951, decidisse construir o projeto funcional de Meister, preterindo os dois primeiros colocados no concurso. ${ }^{58}$

$\bigcirc$ artigo de Azevedo teria influenciado também as escolhas para o Centro Cívico. ${ }^{59}$ Isto é, o governo decidiu finalmente por uma proposta 
moderna, preterindo a concepção tradicional para o novo complexo administrativo incluída no plano Agache (figura 1). Uma das primeiras ações da Ceoc foi encomendar um novo projeto para o centro, "sendo escolhido o que concretizava as tendências da arquitetura contemporânea". 60

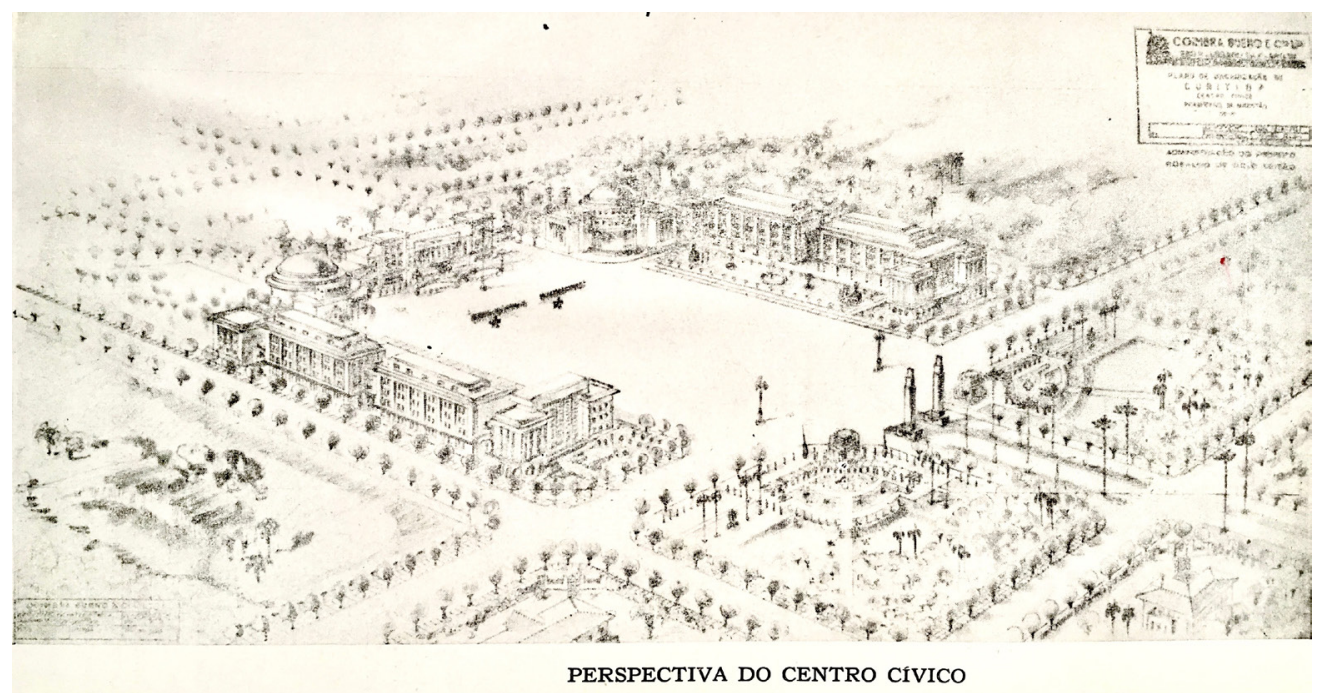

Figura 1 - $\bigcirc$ Centro Cívico do Plano Agache. Fonte: Prefeitura Municipal de Curitiba. Boletim PMC, ano 2, n. 12, nov./dez. 1943, p. 32.

Os tradicionalistas, que haviam reacendido o debate contra a escolha do governador para o teatro, ${ }^{61}$ tampouco deixaram passar o Centro Cívico. Em 1952, com as obras prestes a iniciar, o historiador e positivista David Carneiro 62 publicou no jornal curitibano $\bigcirc$ Dia (de oposição a Munhoz da Rocha) um passeio imaginário pelo complexo já pronto, a partir do modelo que vira em maquete. Apesar de reconhecer as vantagens, para o Paraná, de uma obra grandiosa como aquela, exercitou largamente o sarcasmo, notando os efeitos exagerados buscados pelos modernistas (ao final do texto, contrastava-os, como se fossem meras artificialidades, ao panorama da "cidade emoldurada pelas montanhas azuis da Serra do Mar"). Não havia o que fazer, contudo, a não ser desejar "que em muitos pontos essenciais os arquitetos pudessem reconsiderar os seus projetos recaindo em fórmulas mais conservadoras", o que não ocorreria. No mesmo texto, Carneiro reeditou um argumento que parece ter usado alguns anos antes, quando era membro da banca do concurso para o novo teatro: ${ }^{63}$ gostaria que a Assembleia Legislativa se parecesse efetivamente com um parlamento, a exemplo do "capitólio de Washington", o "Congresso de Buenos Aires ou o Palácio Legislativo do Uruguai". 64 Era a Carneiro que Fernando Corrêa de Azevedo se referia ao responder, no artigo mencionado
60. "Os primeiros estudos foram apresentados poucas semanas" depois da criação da Comissão. Mensagem apresentada à... (1952, p. 193).

61. Dudeque (2001, p. 164-165).

62. David Antônio da Silva Carneiro (1904-1990), formado engenheiro pela Universidade do Paraná, foi um conhecido positivista e historiador especializado em temas regionais, membro ativo do Instituto Histórico, Geográfico e Etnográfico do Paraná. Filho mais velho (e homônimo) de um dos mais ricos industriais do mate, produto dominante no Paraná da Primeira República. Era professor da Escola de Música e Belas Artes do Paraná em 1948, quando foi realizado $\mathrm{o}$ concurso para o teatro.

63. Pacheco (2010, p. 20).

64. Carneiro (1952, p. 3) 
65. Azevedo apud Dudeque (2001, p. 417).

66. Cf. Gnoato (2007). Há semelhança no modo como são narradas as façanhas de dois engenheiros-arquitetos curitibanos dessa época: Romeu Paulo da Costa, que projetou a biblioteca cf. Galani (2015), e Rubens Meister, autor do teatro cf. Gnoato (2007). Eram ambas construções especializadas em cujo planejamento deveriam ser consideradas, em primeiro plano, as funções específicas a que se destinavam, segundo os ditames da arquitetura funcional. Até então, Costa aprendera sobre bibliotecas tanto quando Meister sobre teatros: pouco. Ambos teriam se aprofundado de forma autônoma nas técnicas pertinentes, procurando aconselhar-se com autoridades no Brasil e no exterior.

67. "Curitiba, Brazil, plans 'official' theater", Architectural Record, dezembro de 1952. Reproduzido em Dudeque (2001, p. 418-419).

68. Mensagem apresentada à... (1951, p. 115).

69. Os pavilhões foram projetados pelo arquiteto David Xavier de Azambuja, que será apresentado adiante. Gonçalves (2006, p. 167).

70. Cf. Comissão de Comemorações... [s. d.].

71. Pacheco (2010, p. 31).

72. A "maturação e oficialização do movimento" moderno, nos anos 1930 (Simioni, 2013, p. 5), foi coroada pela construção, em pleno Estado Novo, do edifício do Ministério da Educação e Saúde (MES) em arquitetura moderna, preterindo-se propostas acadêmicas. acima: "[d]izem alguns que um teatro deve se conhecer por fora que é um teatro, como uma igreja se conhece que é uma igreja". ${ }^{65}$

No final de 1952, a revista americana Architectural Record publicou uma nota sobre o Teatro Guaíra. Meister, autor do projeto, era sob diversos aspectos um autodidata, e acompanhava a revista, que the servia, entre outras, para "complement[ar] sua formação específica em arquitetura". ${ }^{60} \bigcirc$ artigo reconhecia a querela e, de certo modo, referendava a escolha do projeto moderno:

O segundo [na verdade, o terceiro] colocado [...] será construído [...] após intenso debate público precipitado pela escolha de um desenho mais tradicional para receber o primeiro prêmio. O projeto a ser construído foi feito por Rubens Meister, professor de arquitetura na Escola de Engenharia da Universidade do Paraná. Terá capacidade para 1.900 pessoas e oferecerá instalações sofisticadas para ópera, concertos, peças, exibição de filmes e televisão. ${ }^{67}$

Outras duas obras que reforçam a preferência inequívoca pelas ideias "contemporâneas" parecem ter gerado menos polêmica. A necessidade da nova biblioteca pública era provavelmente mais consensual entre as diferentes frações da classe dominante, quaisquer que fossem seus posicionamentos ideológicos. Isso pode ter levado reacionários e opositores políticos a pouparem a biblioteca, concentrandose em obras vistas como menos essenciais. E talvez a ousadia da biblioteca estivesse mais em sua concepção inovadora - acesso livre às estantes, coleções ambulantes para cidades do interior, filmoteca e investimento em intercâmbio com congêneres estrangeiras $^{68}$ - do que em seu aspecto exterior, menos ousado que o do teatro. Previu-se para o início de 1954, na sequência das comemorações, a realização da Exposição Internacional do Café e da Feira de Curitiba. $\bigcirc$ parque de exposições construído especialmente para os eventos seguia, também, linhas modernas, ${ }^{69}$ mas talvez seu caráter temporário tenha desviado a atenção dos críticos. ${ }^{70}$

A iniciativa de Munhoz da Rocha, ao colocar em marcha o vasto programa de obras para o centenário e atualizar seus projetos de acordo com as concepções modernas, produziria a introdução triunfal do modernismo no Paraná. Suas escolhas significaram uma espécie de imposição. De cima para baixo, pois nem o "mercado" tinha aderido à novidade e, ao longo de toda a década de 1950, "as empreiteiras insistiam em construir edifícios habitacionais segundo estilos pré-modernos". 71 Imposição, também, de um grupo da elite favorável aos modernos sobre outro, reacionário. Assim como ocorrera em nível nacional com a construção do Ministério da Educação e Saúde, a cargo do ministro do Estado Novo Gustavo Capanema, era o patrocínio estatal "ilustrado" que consolidava a hegemonia dos modernos. ${ }^{72}$ 
Quem apresentou o novo projeto para o Centro Cívico, por volta de outubro de 1951, foi David Xavier de Azambuja. Curitibano de nascimento, formara-se na Escola Nacional de Belas Artes e era professor da Faculdade Nacional de Arquitetura, ambas no Rio de Janeiro. Azambuja radicou-se no Rio, adaptando-se "a uma realidade bem mais complexa e pródiga em oportunidades" profissionais que a de Curitiba, assim como fizera o também curitibano Vilanova Artigas, radicado mais ou menos na mesma época em São Paulo. ${ }^{73}$ Azambuja tinha, senão elos, ao menos afinidades com o grupo próximo a Munhoz da Rocha ${ }^{74}$ e possivelmente foi convidado a apresentar uma proposta. No Rio, Azambuja formou uma equipe de profissionais vinculados ao movimento moderno, como Olavo Redig de Campos, Sérgio Rodrigues e Flávio Régis do Nascimento, em cujo escritório reuniam-se. ${ }^{75} \bigcirc$ próprio Lúcio Costa teria acompanhado "atentamente" os primeiros passos do projeto $^{76}$ e, segundo relato de um dos membros da equipe, visitava as reuniões para debater alguns de seus principais aspectos. Sua opinião teria sido decisiva, por exemplo, para as escolhas sobre o "dimensionamento" e a "suntuosidade" da praça do Centro Cívico."77 $\bigcirc$ projeto, portanto, estava nas mãos dos profissionais mais prestigiados, membros da chamada "escola carioca".

Tratava-se de trunfo do governo estadual, sem dúvida - e seus mandatários tinham consciência do feito que fora assegurar tamanho prestígio. $\bigcirc$ contrato assinado entre o governo e o primeiro chefe da $\mathrm{Ceoc}$, o engenheiro Elato Silva, ${ }^{78}$ em dezembro de 1951, estabelecia que, na construção do Centro Cívico e das demais obras, ele deveria "obedecer aos projetos arquitetônicos elaborados", assegurando-se a primazia dos arquitetos do Rio. ${ }^{79}$

No projeto do Centro Cívico, o paranaense Azambuja agia precisamente como um dos brasileiros que, formando-se no Rio, "se transformaram em mensageiros da arquitetura moderna". ${ }^{80}$ Devido à hegemonia conquistada pelo grupo de Oscar Niemeyer e Lúcio Costa, realizar projetos no interior do país significava, àquela altura, "disseminar a linguagem carioca", atuando como "arquiteto-peregrino" nos rincões de um Brasil ainda por modernizar. ${ }^{81}$ E modernizar significava também nacionalizar. Era Lúcio Costa que, no "campo arquitetônico", elaborava "a base teórica da retradução de valores, com vistas à formação de uma nova 'identidade' nacional" . 82 Para tanto, os modernos buscaram assegurar o poder simultâneo sobre o passado e sobre o futuro, numa "dupla atuação" bem ilustrada pela parceria de Costa e Niemeyer: "o primeiro como urbanista e diretor de arquitetura e história do Sphan [Serviço do Patrimônio Histórico e Artístico Nacional], o segundo como arquiteto de grandes projetos, sobretudo na esfera pública" ${ }^{83}$ Para Costa, deixando clara sua visão integrada de
74. Ibid. (p. 411).

75. Mueller (2006, p. 62).

76. Ibid. (p. 167).

77. Ibid. (p. 169).

78. Elato Silva presidiu a Ceoc de $1^{\circ}$ de dezembro de 1951 até o final de 1953.

79. Termo de contrato... [s. d.].

80. Segawa (1998, p. 142).

81. Ibid.

82. Cavalcanti (2006, p. 49).

83. Ibid. (p. 15). 
84. Chuva (2003, p. 320).

85. Cerchiaro (2016, p. 5)

86. Pacheco (2010, p. 36). passado e futuro, a "função primordial" do Sphan era "dar concretude à nação, não somente desvendando a todos os brasileiros aquilo que, embora existente, se encontrava escondido, mas, também, construindo efetivamente sua materialidade". ${ }^{84}$ Esse sentido nacional e missionário transmitiu-se pela atuação dos profissionais da escola carioca.

Na superfície, tratava-se de levar a novidade da arquitetura moderna para os quatro cantos, produzindo ao mesmo tempo a interiorização do moderno (interesse dos formuladores e disseminadores da escola, como Azambuja) e a modernização do interior (interesse de políticos ambiciosos como Munhoz da Rocha e do grupo de intelectuais favoráveis ao modernismo que o rodeava). Todos ganhavam. Olhando mais de perto, contudo, a substituição dos estilos tradicionais, referenciados diretamente na Europa, por um moderno que, se não fosse originalmente brasileiro, era ao menos elaborado no Brasil, reforçava um sentido de nação que tomava por referência os grandes centros - naqueles anos de hegemonia da escola carioca, sobretudo o Rio de Janeiro. Nesse sentido, o moderno da escola carioca era uma força centrípeta que contribuía para nacionalizar as regiões. Longe de homogeneizar, contudo, esse processo particular de nacionalização tratava de as situar, por meio de edifícios monumentais, numa nação internamente diferenciada, com centro produtor e periferias consumidoras. Desse ponto de vista, a arquitetura reforçava uma narrativa de nação centrada numa capital cosmopolita, para onde convergia a vida política e cultural de todas as regiões. Em seguida, processada no Rio, a diversidade regional retornava às regiões como modernidade nacional. Essa relação entre centro nacional e periferias regionais apoiava-se, também, em certa ambiguidade própria da arquitetura moderna, pois se sua linguagem era marcada pela "racionalidade, objetividade e propensão a internacionalizar-se", ao mesmo tempo atribuir-the um "caráter nacional" era um modo de "legitimar tal arquitetura no contexto brasileiro" .85

A dinâmica, é claro, encerrava relações de poder entre os polos naçãoregiões. Não impressiona que, alguns anos mais tarde, na São Paulo emergente como motor industrial do país, surgiria uma escola moderna de arquitetura com linguagem própria, o brutalismo, capaz de promover uma narrativa alternativa de nação, em contraponto à narrativa da escola carioca; e que a primeira "escola" propriamente paranaense, o "grupo do Paraná", se consolidaria, então, sob forte influência dos paulistas. Segundo Paulo Cesar Pacheco, a influência da escola carioca teria ficado resumida a um "curto período de tempo" - entre 1948 e 1960 - no qual, em Curitiba, "se buscava ser moderno, mas sem se saber como". 86 Porém, as lutas para importar o moderno do Rio na época do centenário sugerem o contrário: o grupo de elite no poder sabia que o Paraná só poderia ser moderno se fosse, em primeiro lugar, brasileiro. Mostram-no bem dois acontecimentos relacionados a essa busca. 
No início de 1952, ainda antes de as obras começarem, o secretário de Educação e Cultura do estado escreveu pessoalmente a Le Corbusier, maior influenciador dos arquitetos do Rio, convidando-o para visitar Curitiba e "estudar alguns projetos que o governo estadual pretendia the confiar". ${ }^{87}$ Ironicamente, o secretário era Newton Carneiro, irmão mais novo de David, o principal opositor dos projetos modernos para o teatro e o Centro Cívico. Homem de confiança de Munhoz da Rocha, Newton seria presidente da Comissão Central de Comemorações do Centenário e atuaria em sentido contrário ao irmão renitente, facilitando a introdução do modernismo no Paraná. $\bigcirc$ convite a Le Corbusier provavelmente se referia ao Centro Cívico e, nesse caso, "confiar" deve ter sido um exagero de interpretação sobre a intenção do secretário, pois a equipe de Azambuja já vinha trabalhando no assunto havia meses. A intenção talvez fosse obter sua chancela, aumentando o prestígio do empreendimento. Conforme a correspondência, "em princípio a ideia the parece[u] atraente, mas, sem que se saiba porquê, o assunto não [teve] continuidade". ${ }^{88} \bigcirc$ contato com Le Corbusier mostra o crescimento das pretensões para o centenário: de profissionais que trabalhavam em Curitiba, como Rubens Meister, avançou-se para os expoentes da escola carioca, Lúcio Costa à frente, até chegar em seu inspirador, Le Corbusier.

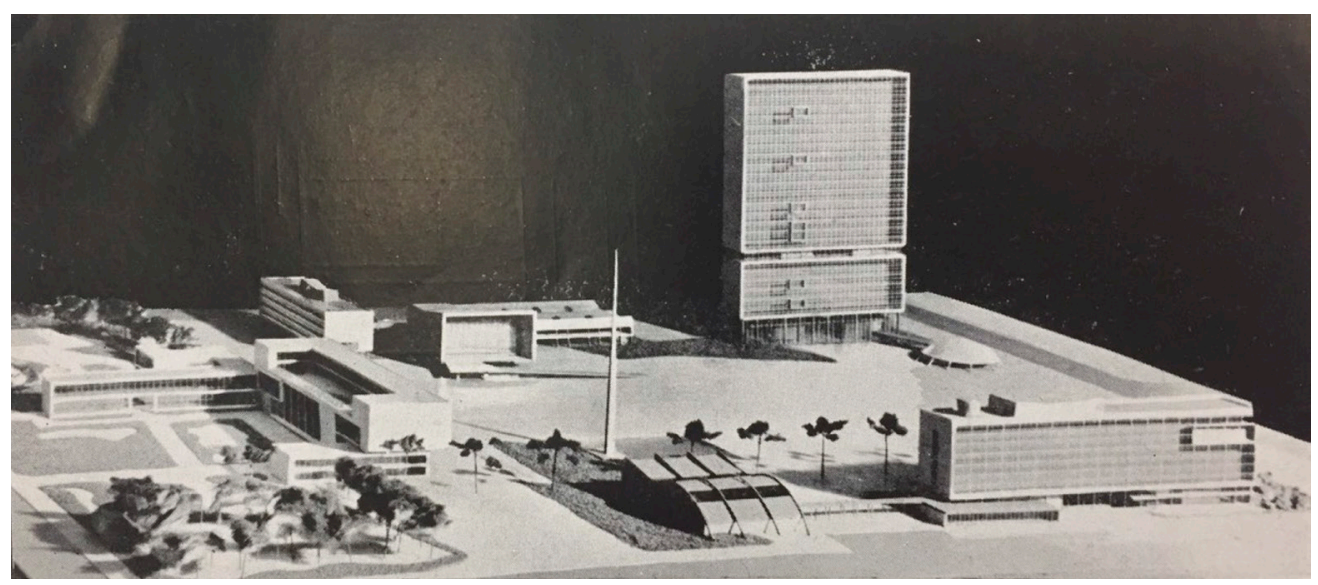

Figura 2 - Detalhe da maquete do Centro Cívico em L'Architecture d'Aujourd'hui.Fonte: "Centre Civique", L'Architecture d'Aujourd'hui, n. 42, 1952, p. 48.

Embora o contato não tenha avançado, pode ter contribuído para produzir um resultado extremamente positivo. Segundo um dos membros da equipe de Azambuja, a satisfação de apresentar "a maquete na 2ª Bienal de São Paulo (dezembro de 1953 a fevereiro de 1954) só foi superada quando [a] vimos impressa na famosa revista especializada L'Architecture d'Aujourd'hui, junto às principais arquiteturas mundiais". ${ }^{89}$
87. Santos apud Pacheco (2010, p. 89).

88. Ibid.

89. Mueller (2006, p. 169). 
90. Centre Civique (1952, p. 48).

91. Ibid.

92. Ibid.

93. Ouro Preto (1952, p. 1).
De fało, o projeto mereceu uma página na edição dupla de 1952 inteiramente dedicada à arquitetura brasileira (figura 2). ${ }^{90} \bigcirc$ Centro Cívico de Curitiba era surpreendentemente notado, no editorial do dossiê, entre "as belas realizações do Rio, de São Paulo, da Bahia, de Curitiba ou de Cataguazes, germinação incrível que tem deixado o mundo admirado". ${ }^{11}$ Sua inclusão na revista pode ter sido influenciada diretamente por Le Corbusier, que era próximo ao editor André Bloc. E o contato do secretário de estado, nessa hipótese, teria sido providencial.

A inclusão consagrava as obras de Curitiba entre o que de mais avançado se produzia em termos de "arquitetura brasileira". Nas palavras do editor, "o Brasil é considerado no mundo inteiro como a terra eleita pela arquitetura contemporânea mais nova e mais audaciosa". ${ }^{92}$ Mas o reconhecimento não se limitava à arquitetura; abrangia todo o movimento moderno do qual a arquitetura era a ponta mais reconhecida. A apresentação do embaixador brasileiro em Paris àquela edição da revista mostrava a visão oficial sobre o significado amplo dessa consagração do Brasil:

[...] em trinta anos, num dos movimentos de libertação mais extraordinários já conhecidos, seus historiadores, sociólogos, cientistas, romancistas, músicos, pintores, poetas, escultores e arquitetos experimentaram em total liberdade, numa ansiedade pelo novo que difere completamente de todas as experiências culturais ocorridas até então no país.93

A aparição do Centro Cívico no mapa dessa vanguarda convergia com o antigo sonho dos modernos locais: teria o Paraná começado a romper seu retraimento para entroncar na vertente do Brasil moderno?

\section{DOMESTICANDO OS MODERNOS}

As fotos da maquete na revista francesa eram acompanhadas por uma breve apresentação de Curitiba. A cidade, "centro comercial e industrial do estado do Paraná", era retratada como "capital de uma das regiões mais importantes da República Federativa do Brasil", a qual "conhece atualmente uma era de grande prosperidade financeira". Embora ainda não aparecessem nas maquetes fotografadas, eram previstas "diversas obras de arte, estátuas, afrescos, mosaicos", numa "amostra das obras culturais do Brasil de hoje". A apresentação, portanto, reiterava a vinculação de Curitiba, por meio do projeto, ao celebrado Brasil moderno. Havia, contudo, uma dissonância: ao esclarecer sobre a localização da 
cidade em "zona temperada", acrescentava que "ao clima agradável adapta-se muito bem sua população de origem europeia, sobretudo alemã e polonesa". ${ }^{44}$

A afirmação destoava da visão de país do grupo moderno. Primeiro, porque naquele momento já era muito aceita a interpretação de que fora precisamente com o movimento moderno que "o mulato e o negro [foram] definitivamente incorporados como temas de estudo, inspiração, exemplo". ${ }^{95} \mathrm{Na}$ arquitetura, mais especificamente, cabe recuperar o exemplo do prédio do Ministério da Educação e Saúde (MES): Le Corbusier e os arquitetos brasileiros defenderam a construção, à entrada do edifício, de uma estátua do "homem brasileiro" com traços de caboclo, discordando das intenções do ministro Gustavo Capanema, que preferia um "mestiço embranquecido". 96 $\bigcirc$ trecho sobre Curitiba na revista francesa, que embranquecia a representação da cidade, em contraste com a brasilidade esperada pelos europeus, pode ser uma marca da influência do contato do secretário Newton Carneiro com Le Corbusier. Na correspondência, Carneiro poderia ter enviado as informações ou parte delas. $\bigcirc$ certo é que a apresentação evidencia a existência de dois discursos, dificilmente conciliáveis, sobre a relação entre região e nação. Seria o Paraná parte do Brasil moderno, conforme construído por uma geração de escritores, arquitetos e artistas, ou, então, seria um outro Brasil, de clima "temperado" e "origem europeia"?

Esse dilema logo traria problemas para a execução do projeto do Centro Cívico. Ao escolher "importar" o modernismo por intermédio da escola carioca, a elite paranaense acabava importando junto uma brasilidade que não se dobraria ao seu regionalismo. A preferência explícita dos principais arquitetos brasileiros pelo "caboclo" do escultor Celso Antônio, no final dos anos 1930 e início dos 1940, mostra-o bem. Apesar disso, o grupo no poder no Paraná, favorável aos modernos, tentaria domesticar o moderno do Rio e imprimir uma narrativa regional às obras. A parte reacionária da elite, por outro lado, aproveitaria a oportunidade para atacar um aspecto do discurso moderno que the parecia intolerável: a mestiçagem. Tornaria, assim, explícita a tensão entre a brasilidade moderna e a diferença regional produzida, no Paraná, pelo sentimento de branquidade.

No modelo apresentado na revista francesa, destacavam-se, no centro da praça, um espelho d'água e um obelisco, que teria "80 metros de altura" e fora "concebido para realçar a linha horizontal e calma do Palácio do Governo". Fazia parte, portanto, de uma concepção global que harmonizava com os demais elementos. Numa das primeiras formalizações do plano de obras - a lei que instituiu a Ceoc -, a intenção de construir cada edifício aparece em separado, como elementos de um programa mínimo. Isso também ocorre com o "Monumento do Centenário", o qual, pelo texto, não se compreende constituir conjunto com as demais construções. ${ }^{97}$ Isto é, talvez a intenção inicial do governo fosse construir um
94. Centre Civique (1952, p. 48).

95. Candido apud Simioni (2013, p. 8).

96. Cerchiaro (2016, p. 10).

97. Lei $n^{\circ} 674$ de 29 de agosto de 1951. 
98. A publicação, CC Revista sobre as obras do centenário de emancipação política do Paraná, impressa em Joinville pela Impressora Ipiranga, sem data, é citada por Josilena Gonçalves (2006, p. 134) e, aparentemente, com outro nome, por Oscar Mueller (2006, p. 50, passim), que reproduz algumas imagens. Algumas das figuras apareceram em $O$ monumental Centro... (1953, p. 193).

99. Nas diversas imagens publicadas na época reunidas por Dudeque (2001, p. 168-169), é sempre o monumento simples que aparece no centro da praça.

100. Mueller (2006, p. 50)

101. Ibid.

102. Gonçalves (2006, p. 144-145).

103. Cf. Marx (1953).

104. Ibid. (p. 139ss.).

105. Stenzel (1941). monumento comemorativo independente do Centro Cívico. Essa lei antecede, em algumas semanas, a apresentação da proposta pela equipe do Rio. Depois, numa publicação que condensa a proposta, apresentando já uma série de imagens do conjunto e dos edifícios, consolida-se a incorporação do monumento à praça: "em frente ao edifício do Palácio do Governo será instalado o monumento do centenário", isto é, "um obelisco [...] e ao lado deste um belo espelho d'água". 98 Parece razoável, portanto, concluir que o monumento surgiv, entre os membros do governo, como ideia independente, mas foi logo incorporado à praça pelos arquitetos modernos, tornando-se uma das peças fundamentais em sua concepção artística, como sugere a interpretação dada pela revista francesa. As imagens do monumento simples e perfeitamente integrado ao complexo (tal como na figura 2) passaram, então, a circular na imprensa e em publicações oficiais. ${ }^{99}$

As "diversas obras de arte" - ou "modernas estátuas simbólicas", como são chamadas na publicação com a proposta oficial ${ }^{100}$ - têm histórias mais dispersas, pois dependiam de encomendas separadas a diferentes artistas. Apenas algumas foram executadas. Por meio de certos indícios, no entanto, é possível ter ideia do que se pretendia. Na publicação com a proposta oficial, vê-se o modelo de uma estátua parece uma espécie de árvore, talvez até uma araucária estilizada - em frente aos edifícios do Poder Legislativo ${ }^{101}$ e, em algum momento, houve a intenção de revestir a fachada externa do Tribunal do Júri com um mural, como sugere outra maquete. ${ }^{102}$ Roberto Burle Marx chegou a formalizar uma proposta para essa parede, "com pedras locais em duas ou três cores". ${ }^{103}$ Outras obras como relevos e painéis em madeira foram sendo executadas, em ritmos distintos, nas áreas interiores dos edifícios. ${ }^{104}$

Mas nada do que havia sido sugerido ou aprovado pelos arquitetos do Rio assemelhava-se ao que o governador tinha em mente. Munhoz da Rocha contatou o escultor curitibano Erbo Stenzel para que realizasse sua ideia peculiar de monumento. Stenzel tinha sido discípulo do escultor João Turin, pioneiro dessa arte em Curitiba, e no final dos anos 1930 recebera do interventor estadual uma bolsa para se aperfeiçoar no Rio. Estudou na Escola Nacional de Belas Artes e participou de diversas exposições, obtendo certo reconhecimento na capital. Em 1949, com a morte de Turin, o governo estadual de Moysés Lupion convidou-o para retornar a Curitiba, após cerca de uma década na capital, prometendo-the emprego na Escola de Música e Belas Artes do Paraná e um ateliê. ${ }^{105}$ Por sua formação e trajetória, Stenzel era um dos artistas "acadêmicos" aos quais os modernos se contrapunham. Dificilmente sua escolha agradaria aos arquitetos cariocas, mas Stenzel, como a maior parte dos artistas curitibanos da primeira metade do século, dependia economicamente 
do Estado e, portanto, das graças do grupo no poder. ${ }^{106}$ A menor autonomia pode ter sido um dos fatores que levou Munhoz da Rocha a contatá-lo.

Parece que Stenzel foi colocado em situação difícil. De acordo com seu relato, o governador the propôs construir um conjunto de 21 figuras humanas, cada uma representando um estado brasileiro. $\bigcirc$ Paraná, "um adolescente dando um passo à frente", se destacaria, "rompendo correntes que the prendem os pulsos, simbolizando a libertação dos vínculos políticos que o sujeitavam à província de São Paulo". ${ }^{107}$ Uma alegoria nada sutil da independência do estado. A concepção assemelha-se a imagens que circulavam em publicações ligadas ao movimento paranista. Em 1948, uma delas, a revista A Divulgação, ilustrara um editorial intitulado "O Paraná em franca expansão" com a imagem de um trabalhador forte, descalço e com as mangas arregaçadas, rompendo com um urro uma grossa corrente. ${ }^{108}$ A recaída do governador na narrativa ufana próxima ao paranismo mostrava que sua tomada de partido pelo movimento moderno não fora integral ou, então, já vacilava.

$\bigcirc$ escultor teria alegado dificuldades, como a de ser impossível destacar devidamente a figura do Paraná em meio a tantas outras, e propôs uma alternativa que Munhoz da Rocha aceitou: fazer uma só figura, "vertical, em contraste com um grande painel horizontal em baixo relevo, no qual seria sintetizada a história do desenvolvimento do Paraná". ${ }^{109}$ Isto é, a narrativa dos 21 gigantes fora claramente desmembrada em dois elementos: a figura humana vertical e o painel horizontal. Segundo Stenzel, o acordado seria situar o conjunto em frente ao palácio do Executivo. Decorre, todavia, que desse modo as figuras idiossincráticas se misturariam com o conjunto simples de obelisco e espelho d'água projetado pelos arquitetos. Os acréscimos paranaenses ao monumento original não devem ter sido aceitos, pois as fotografias e desenhos presentes nas publicações oficiais, até o final de 1953, mostram sempre o monumento simples conforme concebido no Rio de Janeiro. ${ }^{110}$

Munhoz da Rocha insistiu em sua ideia, provavelmente negociando com a equipe de Azambuja. Em meados de 1953, uma proposta híbrida saiu na revista Brasil Arquitetura Contemporânea. $111 \bigcirc$ "Monumento do Centenário do Paraná" (figura 3) mantinha o espelho d'água e o obelisco, mas havia também uma estátua de formas quase abstratas - pouco a ver com o "adolescente" Paraná representando "o homem que desbravou a região". Atrás, havia o painel com um relevo "descrevendo a história e as riquezas" do estado. "O monumento", dizia a legenda, "será localizado no meio da praça em que se constrói o Centro Cívico de Curitiba, realização de importância no presente surto da arquitetura brasileira". Ao menos uma maquete foi construída de acordo com essa concepção, porém suas imagens não foram amplamente divulgadas, permanecendo em acervo pessoal. ${ }^{112}$
106. É a tese de Geraldo de Camargo: laços de dependência econômica teriam levado "artistas plásticos, na sua maioria filhos de imigrantes com formação profissionalizante”, a servirem como produtores da "apresentação visual" de ideias sobre a identidade paranaense "originadas nas camadas socialmente dominantes" - "literatos lusobrasileiros oriundos de famílias estabelecidas desde a emancipação da província" (Camargo, 2007, p. 9).

107. Gonçalves (2006, p. 151).

108. Machado (2012, p. 82).

109. Gonçalves (2006, p 151). Deve-se ressaltar que essa versão foi dada por Stenzel em entrevista de 1974. Pode ser que, no momento da concepção, sua proposta não tenha sido exatamente essa.

110. Comissão de Comemorações... (1953, p. 51).

111. Monumento do Centenário... (1953).

112. Uma fotografia é reproduzida em Centro Cívico de Curitiba, um espaço identitário, de Oscar Mueller (2006, p. 86 , figura 85 ). 
113. Gonçalves (2006, p. 152).

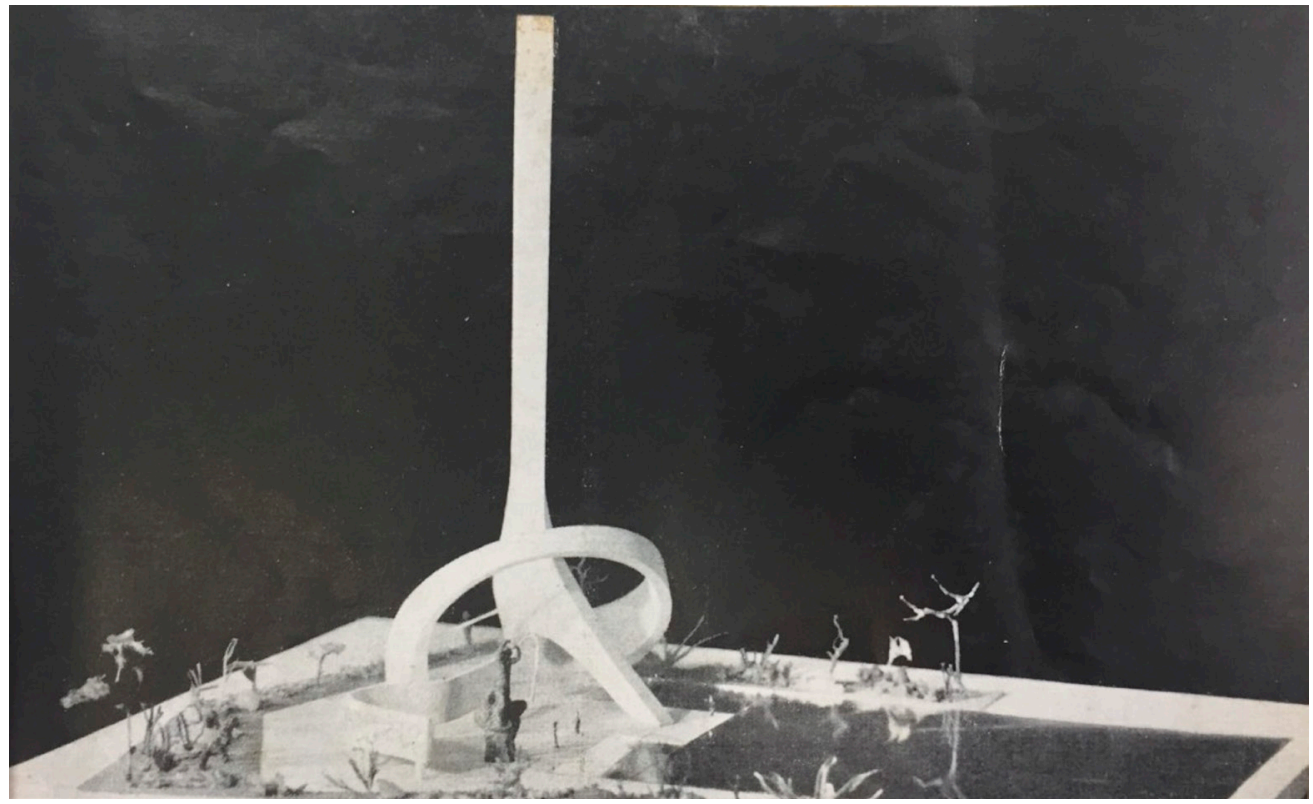

Figura 3 - A proposta híbrida para o "Monumento do Centenário do Paraná". Fonte: "Monumento do Centenário do Paraná", Brasil Arquitetura Contemporânea, n. 1, ago./set. 1953.

A proposta era assinada por Erbo Stenzel, José Pedrosa - escultor conhecido por seu bronze para o Cassino da Pampulha, em Belo Horizonte -, e dois arquitetos da equipe do Rio de Janeiro: Olavo Redig de Campos e Flávio Regis do Nascimento. Parece razoável, assim, entender que se tratava de uma tentativa de compromisso entre os arquitetos e o governador, na qual os arquitetos associavam-se a Stenzel para assegurar o controle sobre as alterações na concepção do monumento. Resultou um modelo híbrido, que incluía os elementos originalmente planejados pelos arquitetos, mas também a figura em que o governador insistia. A fusão, porém, não foi o bastante para enterrar de vez a ideia do "adolescente". Não há outros indícios dessas negociações, mas é certo que, no monumento finalmente mandado construir, a figura humana retornou em lugar da estátua abstrata e o obelisco acabou simplificado. Isso não significa, contudo, que a versão do governador prevaleceu, pois o conjunto inteiro foi deslocado para fora do Centro Cívico, tornando-se uma praça independente a algumas quadras de distância. Segundo Stenzel, a mudança ocorreu "por razões políticas, não sei bem". Pareceu-lhe ter sido uma decisão do próprio governador. $\bigcirc$ artista teria ainda tentado acomodar a estátua do "adolescente" na avenida de acesso ao Centro Cívico, sem êxito: "aí", disse ele, "o jeito foi instalar o monumento na praça". ${ }^{113}$ 
NEGOCIANDO A "COR" DO MONUMENTO

governador não conseguiu incluir sua alegoria do Paraná triunfante no monumento dos modernos. Logo mais, também perderia o controle sobre as formas do gigante que insistira em construir. Como se tratava de uma figura concebida para representar "o homem" do Paraná, as formas e feições compunham um de seus aspectos mais importantes. As tentativas de conciliar o monumento original, simples, com as ideias de Munhoz da Rocha desenrolavam-se ao menos desde o início de 1953. Em fevereiro, Erbo Stenzel recebeu uma carta do escultor Humberto Cozzo contendo uma proposta esboçada à mão. $\bigcirc$ desenho mostrava o obelisco, o painel e a figura gigante dando seu passo adiante e era fruto de conversas mantidas pelos artistas alguns dias antes, quando Cozzo esteve em Curitiba. ${ }^{114}$ Possivelmente nessa ocasião, Cozzo foi contratado para construir o monumento em parceria com Stenzel. Contratá-lo pode ter sido um modo de o governador Munhoz da Rocha esquivar-se da tutela dos arquitetos cariocas, possibilitando-o impor sua ideia do "adolescente". Funcionou, desse ponto de vista, mas a entrada de Cozzo tiraria definitivamente das mãos dos agentes locais o controle sobre o resultado final, pois a obra seria executada no ateliê do artista no Rio de Janeiro.

Havia também motivos práticos para Stenzel associar-se a um profissional de fora: ele não via condições de realizar uma obra daquelas dimensões somente com os recursos técnicos disponíveis em Curitiba. ${ }^{115}$ Talvez isso já tivesse entrado no cálculo que o levara à parceria abortada com o escultor José Pedrosa e os arquitetos modernos. Além disso, Humberto Cozzo, o novo parceiro, tinha assegurado duas outras encomendas para as obras do centenário: uma estátua representando a Justiça, destinada à área em frente ao Tribunal do Júri, 116 e um painel chamado "Alusão ao Trabalho", numa parede interior do palácio do Executivo. ${ }^{17}$ Em 1953, já trabalhava ao menos nesta última. Os escultores conheciam-se do Rio, provavelmente do ambiente da Escola Nacional de Belas Artes. Cozzo, paulista, radicara-se na capital, fora premiado no Salão Nacional de Belas Artes e era autor de diversas encomendas, um experiente escultor "acadêmico" requisitado em todo o país.

Uma de suas obras, instalada em Curitiba em 1951 - antes de qualquer intenção de se associarem para o centenário -, revela a amizade entre os dois e ajuda a compreender o modo como organizariam a parceria. Em maio de 1951, Cozzo havia escrito a Stenzel pedindo-lhe que auxiliasse o cunhado a encontrar uma pensão na cidade, pois ele passaria alguns dias cuidando da instalação da estátua em homenagem à Força Expedicionária Brasileira. ${ }^{118} \bigcirc$ trabalho, feito no ateliê do Rio e entregue pronto em Curitiba, preconizava o modelo que logo mais os profissionais acertariam para realizar as obras do
114. Carta de Humberto Cozzo a Erbo Stenzel, 6 fev. 1953. Cf. Cozzo [s. d.].

115. Gonçalves, (2006, p. 153).

116. Uma carta sugere que as tratativas para contratar Cozzo para realizar a estátua da Justiça ocorriam ao menos desde meados de 1952. Cf. Pereira (1954).

117. Ibid. (p. 139).

118. Carta de Humberto Cozzo a Erbo Stenzel, 29 maio 1951. Cf. Cozzo [s. d.]. 
119. Carta de Humberto Cozzo a Erbo Stenzel, 28 mar. 1953. Cf. Cozzo [s. d.].

120. Ibid.

121. Cozzo, Maquete. [s. d.]. Fotografias anexadas às cartas.

122. Gonçalves (2006, p. 153). Trechos da entrevista são reproduzidos em reportagem de 1972 . O criador fala... (1972, p. 3).

123. Carta de Humberto Cozzo a Erbo Stenzel, 30 de abril de 1953. Cf. Cozzo [s. d.]. monumento do centenário. Cozzo e seus assistentes no Rio esculpiriam em granito o gigante e os grandes blocos do painel ondulado. As peças seriam entregues prontas em Curitiba. No painel, Stenzel esculpiria um relevo retratando a história econômica do Paraná e, no verso, Poty Lazzarotto, ilustrador que fora um dos responsáveis pela revista moderna Joaquim, faria um mural de azulejos com a história local sob o enfoque político. Cozzo, a princípio, não ficou muito satisfeito com a contratação do ilustrador curitibano, pois já tinha ele mesmo "um plano para o painel de mosaico", 119 mas não conseguiv evitar a contratação de Poty.

O painel em relevo foi concebido e modelado por Stenzel, em diálogo com Cozzo e seguindo orientações historiográficas de José Loureiro Fernandes, reconhecido antropólogo e professor da Universidade do Paraná. ${ }^{120}$ Do mesmo modo, o gigante, embora feito no Rio, deveria seguir em linhas gerais a ideia negociada entre Stenzel e o governador. Não parece, todavia, terem sido preservados esboços do artista curitibano. Depois da conversa presencial, possivelmente em janeiro de 1953, Cozzo começou a preparar uma série de modelos cujas fotos ele enviaria a Curitiba, para que o colega acompanhasse a evolução do trabalho. Uma das primeiras fotografias mostrava uma maquete baseada no desenho à mão que meses antes ele enviara a Stenzel. Simulava todos os elementos do monumento: o obelisco, o painel, o espelho d'água e uma figura humana, ainda com traços indefinidos (figura 4). ${ }^{121}$ Parecia-se com - modelo a ser publicado, alguns meses depois, em Brasil Arquitetura Contemporânea, mas já com o gigante "Paraná" em lugar da figura abstrata dos pioneiros. Anos mais tarde, Stenzel diria não ter gostado daquela maquete. "Apresentei o projeto para Cozzo", disse em entrevista, em 1972, "e ele, mais tarde, voltou com um pequeno modelo da imagem, só que contrariando o que eu queria: ao invés de inclinada, estava em posição reta. Não gostei, mas como o tempo não permitia reparos, ela foi feita assim mesmo." 122

Discordando, talvez, dessa concepção, Stenzel anunciou sua vontade de desistir da parceria no final de abril. ${ }^{123}$ Fazia sentido, se suas determinações não estavam sendo seguidas e a obra seria totalmente executada no Rio. Se a desistência se confirmou, o artista curitibano teria deixado a estátua, ainda na fase de preparação dos primeiros modelos, aos cuidados exclusivos de Cozzo, mas não é possível ter certeza. $\bigcirc$ certo é que Cozzo pediu a Stenzel que esperasse alguns dias, para que pudessem discutir pessoalmente o assunto em Curitiba. Ao mesmo tempo, Stenzel seguiu trabalhando na concepção do painel em baixo-relevo e mais tarde continuou a receber fotografias dos avanços na preparação da estátua, a respeito dos quais Cozzo pedia-the a opinião. Portanto, ainda que Stenzel tenha mesmo desistido, manteve-se atento ao andamento do trabalho. 


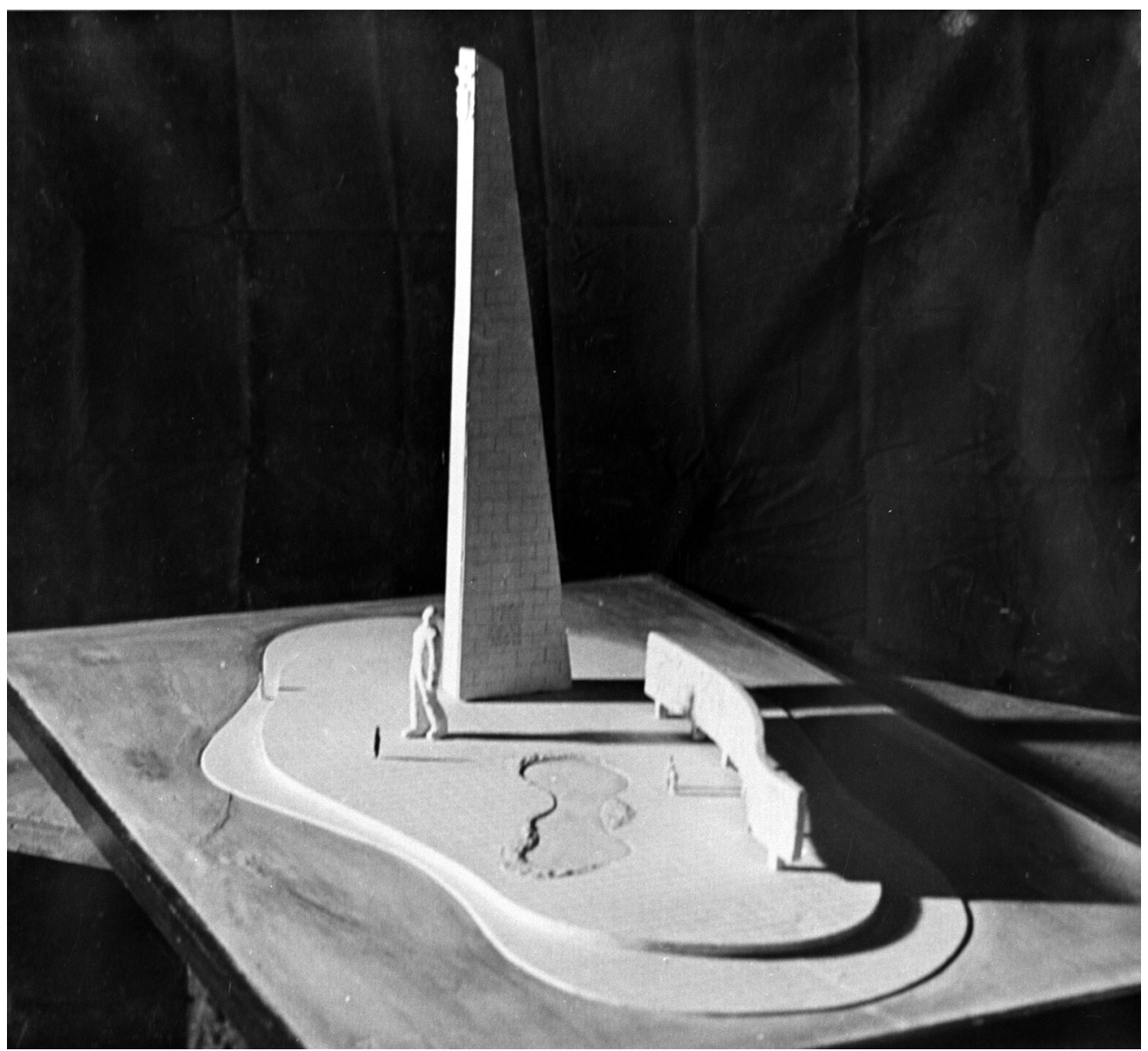

124. Stenzel; Cozzo. [s. d.].

125. No Brasil da era da democracia racial, encontrava-se em plena vigência o sistema de classificação racial por "cor" descrito por Oracy Nogueira (2006 [1955]), no qual a raça percebida de um indivíduo decorre da c o m bi n a çã o d e características físicas, como tipo do cabelo, traços faciais e cor da pele, e características sociais, como apresentação e refinamento. Cf. Guimarães (2011).

Figura 4 - A maquete de Humberto Cozzo. Fonte: Fundação Cultural de Curitiba, Fundo Erbo Stenzel, pasta "A Praça 19 de Dezembro na obra de Erbo Stenzel".

Fotografia posterior (talvez aquela mencionada em carta de 30 de abril) mostra o desenvolvimento da figura: Cozzo havia feito uma escultura de argila e, a seus pés, vê-se uma estátua de gesso, menor, que parece ter sido uma das primeiras tentativas (figura 5). A figura menor ainda tinha traços indefinidos, mais voltada para expor a ideia da forma e postura da estátua. ${ }^{124}$ Já no modelo maior vê-se pela primeira vez uma figura com feições reconhecíveis. E pode-se identificá-las facilmente como as de um homem branco, com nariz fino e cabelos lisos, isto é, dotada de características com significado racial que permitem atribuir "cor" até mesmo a uma estátua de granito cinza. ${ }^{125}$ Não há indícios de discussão sobre essas escolhas na correspondência, de modo que ou os dois estavam de acordo - nesse caso, é possível que o desenho tenha seguido orientações anteriores do próprio Stenzel - ou Stenzel já havia desistido de todo de influenciar na obra, o que parece improvável. 
Figura 5 - $\bigcirc$ modelo de argila, "branco". Fonte: "Modelos em barro em escalas diferentes da estátua do Homem Nu, obra dos escultores Erbo Stenzel e Humberto Cozzo". Acervo Casa da Memória, Diretoria do Patrimônio Cultural, Fundação Cultural de Curitiba, Coleção Erbo Stenzel (ref.: SN, 6967). I fotografia, $p / b$.

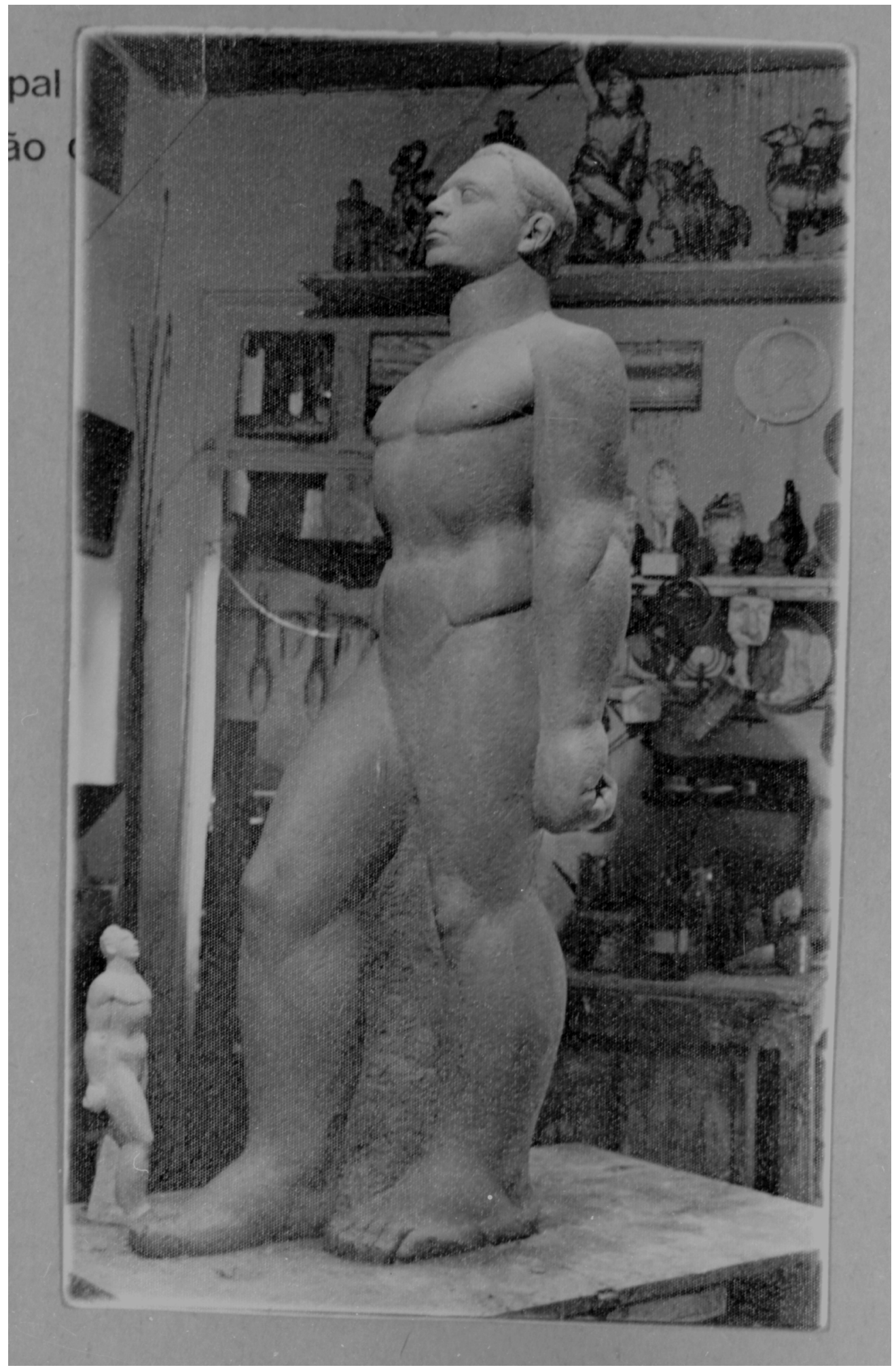




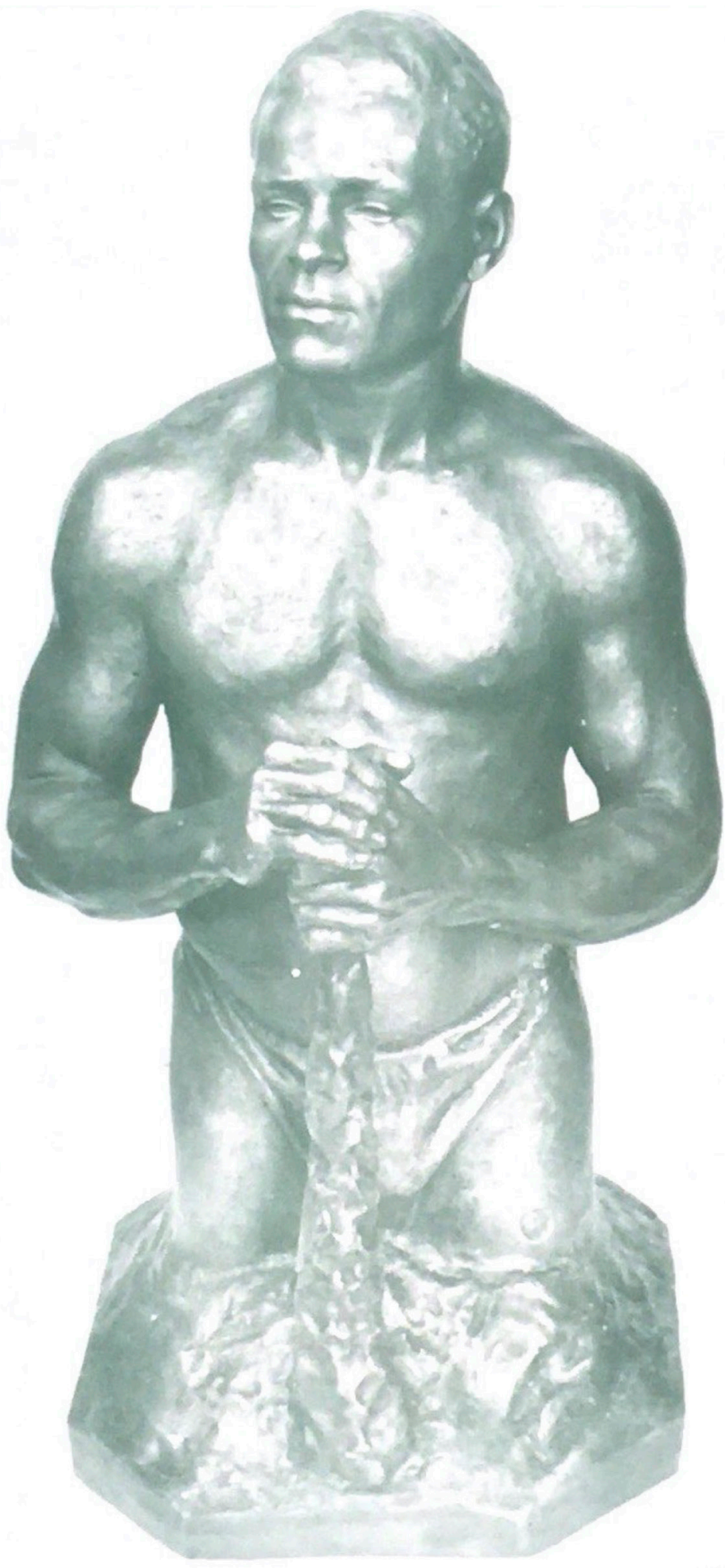

Figura 6 - Erbo Stenzel, Torso de Trabalhador, 1941. Fonte: Museu de Arte do Paraná. "Erbo Stenzel, 1911 - 1989: escultura, desenho, gravura". Exposição realizada por ocasião do décimo quinto aniversário de falecimento do artista, Curitiba, 6 de julho a 25 de agosto de 1995 (panfleto). 
126. Stenzel (1941).

127. Carta de Humberto Cozzo a Erbo Stenzel, 28 de março de 1953. Cf. Cozzo [s. d.].

128. Dávila (2003, p. 22).
A escolha por esculpir um homem de traços brancos parece ter sido feita com naturalidade. De um lado, devem ter sido importantes as expectativas de seu idealizador. Perderam-se os detalhes da primeira concepção acordada entre Stenzel e o governador, mas é possível ter uma ideia de como a estátua do Paraná se distinguiria em meio a 20 outras figuras semelhantes. A proposta de que deveria ser um "adolescente", segundo relato de Stenzel, sugere que as feições seriam uma dessas marcas. Outras características, como marcas regionais ou traços racializados com conotação regional, poderiam ter sido empregadas. Embora trate-se aqui apenas de conjecturas, veremos a seguir que boa parte da elite curitibana esperava que, se o Paraná seria representado numa figura humana, que fosse uma figura "branca", correspondente ao modo como imaginavam o tipo físico paranaense. Por agora, basta lembrar que mesmo a fração dessa elite simpática ao movimento moderno - Munhoz da Rocha à frente - entrov em choque com os modernos do Rio quando eles passaram a bloquear a imposição de uma narrativa regionalizante ao complexo do Centro Cívico. Do mesmo modo, o problema da "cor" do gigante cinzento acabaria por evidenciar que a combinação de raça e região limitava a adesão da elite paranaense a certa vertente do modernismo considerada brasileira demais.

De outro lado, complementando a perspetiva do governador, a escultura de um Torso de Trabalhador modelado por Stenzel na Escola Nacional de Belas Artes em 1941 oferece mais pistas (figura 6). ${ }^{126}$ Homem forte, de músculos bem definidos e expressão serena, mas decidida, seu trabalhador de traços brancos aproximava-se da figura preparada por Cozzo em sua oficina. Assim como o escultor paulista sugerira a Stenzel, numa carta, modernizar as figuras que havia desenhado para o painel em baixo-relevo, ${ }^{127}$ o gigante de granito pode ter sofrido influência do trabalhador de 1941, como um parente modernizado. $\bigcirc$ mais importante, porém, é o parentesco entre o modo como Stenzel concebera o trabalhador, no início dos anos 40, e o modo como ele e Cozzo concebiam o Paraná "adolescente" ou, noutra versão, "o homem que desbravou" o estado, no início dos anos 1950: tão branqueado e heroico quanto distante da representação popular e mestiça elaborada pelos intelectuais e artistas modernos.

Exatamente por tal motivo, acomodava-se melhor às expectativas de quem encomendava esse tipo de trabalho. Novamente, um exemplo conhecido de adesão limitada às ideias do movimento moderno é a reação de repúdio do ministro Gustavo Capanema, em 1937, à estátua apresentada pelo escultor Celso Antônio. Seria uma representação monumental do "homem brasileiro" instalada em frente ao novo Ministério da Educação e Saúde; edifício e estátua que "se complementarão de maneira exata e necessária", como teria dito o ministro. ${ }^{128}$ No entanto, apesar de bancar a construção do inovador edifício moderno, Capanema 
recusou a proposta para a estátua, pois ela retrataria o "homem brasileiro" com "feições sertanejas, barrigudo e [com] compleição pouco atlética". ${ }^{29} \bigcirc$ ministro enviou a conhecidos antropólogos a seguinte indagação, para guiar uma nova proposta: "como será o corpo do homem brasileiro, do futuro homem brasileiro, não do homem vulgar ou inferior, mas do melhor exemplar da raça?" 130 Contudo, Celso Antônio, recomendado para a tarefa por Lúcio Costa, ${ }^{131}$ teria se recusado a submeter-se à banca formada pelos especialistas, afirmando, em resposta, que quando olhava para o Brasil, era aquilo que via. ${ }^{132}$ Após atrasar pagamentos, Capanema cancelou a encomenda. ${ }^{133} \bigcirc$ trabalhador acadêmico de Stenzel, de 1941, talvez ficasse mais à vontade no papel esperado pelo ministro, assim como a estátua de traços "claros" que fora modelada na oficina de Cozzo. Nesse sentido, é provável que a limitada reflexão sobre a brasilidade, por parte de escultores "tradicionalistas" como Cozzo ${ }^{134}$ e Stenzel, convergisse com as ideias mais conservadoras sobre o "homem brasileiro", encampadas por políticos intelectuais tais como Capanema e Munhoz da Rocha; agentes que haviam aderido com ressalvas ao modernismo, prontos para dar um passo atrás quando a brasilidade dos modernos confrontasse suas próprias projeções, mais conservadoras.

Ao contrário de Capanema, Munhoz da Rocha não teve a chance de recuar, pois a estátua do centenário havia saído do controle. Enquanto esculpia os painéis em Curitiba, Stenzel acompanhava por fotografias a preparação das grandes peças da estátua em granito: primeiro os pés e as canelas, depois as coxas, o tronco. Em 19 de dezembro de 1953, durante as festas do centenário, a praça foi inaugurada apenas com o obelisco. $\bigcirc$ trabalho atrasava na medida em que também atrasavam as parcelas devidas aos escultores, e Cozzo pressionava Stenzel para que cobrasse seus interlocutores no governo. A contar pela frequência das cartas, o trabalho diminuiu de ritmo em 1954. Munhoz da Rocha parecia ainda ter esperança de realizar uma inauguração notável, talvez para as comemorações de 101 anos de criação do estado, no 19 de dezembro seguinte - a biblioteca, que não ficou pronta a tempo, foi inaugurada em dezembro de 1954. Em janeiro, ele solicitou aos escultores que iniciassem a montagem do monumento na praça somente quando tudo estivesse pronto. ${ }^{135}$ Mas tudo demorou mais do que o esperado. $\bigcirc$ homem e os painéis parecem ter sido instalados ao longo do primeiro semestre de 1955 e seriam entregues oficialmente em 15 de junho, cerca de um mês depois de Munhoz da Rocha renunciar ao governo do estado para assumir o Ministério da Agricultura do presidente Café Filho. $\bigcirc$ fato de ter sido entregue oficialmente numa quarta feira às 10 h30 da manhã "sem cerimonial de protocolo"136 sinaliza que o monumento tinha perdido, para as autoridades, a aura que cercara sua concepção.
129. Cavalcanti (2006, p. 51).

130. Ibid.

131. Cerchiaro (2016a, p. 75).

132. Dávila (2003, p. 22).

133. Cavalcanti (2006, p. 52).

134. Para Cavalcanti (2006, p. 230), "os modernos possuíam [...] um projeto visual de nação incomparavelmente mais globalizante, sofisticado e inclusivo da complexa realidade brasileira. Basta compararmos as concepções de Brasil contidas nos painéis de Portinari sobre os ciclos econômicos brasileiros na ante-sala do gabinete do ministro no MES e as métopas de Cozzo sobre as riquezas naturais e espirituais da nação nas galerias térreas do Ministério da Fazenda”.

135. Carta de Humberto Cozzo a Erbo Stenzel, $11 \mathrm{de}$ janeiro de 1954. Cf. Cozzo [s. d.].

136. O monumento da... (1955, p. 3). 


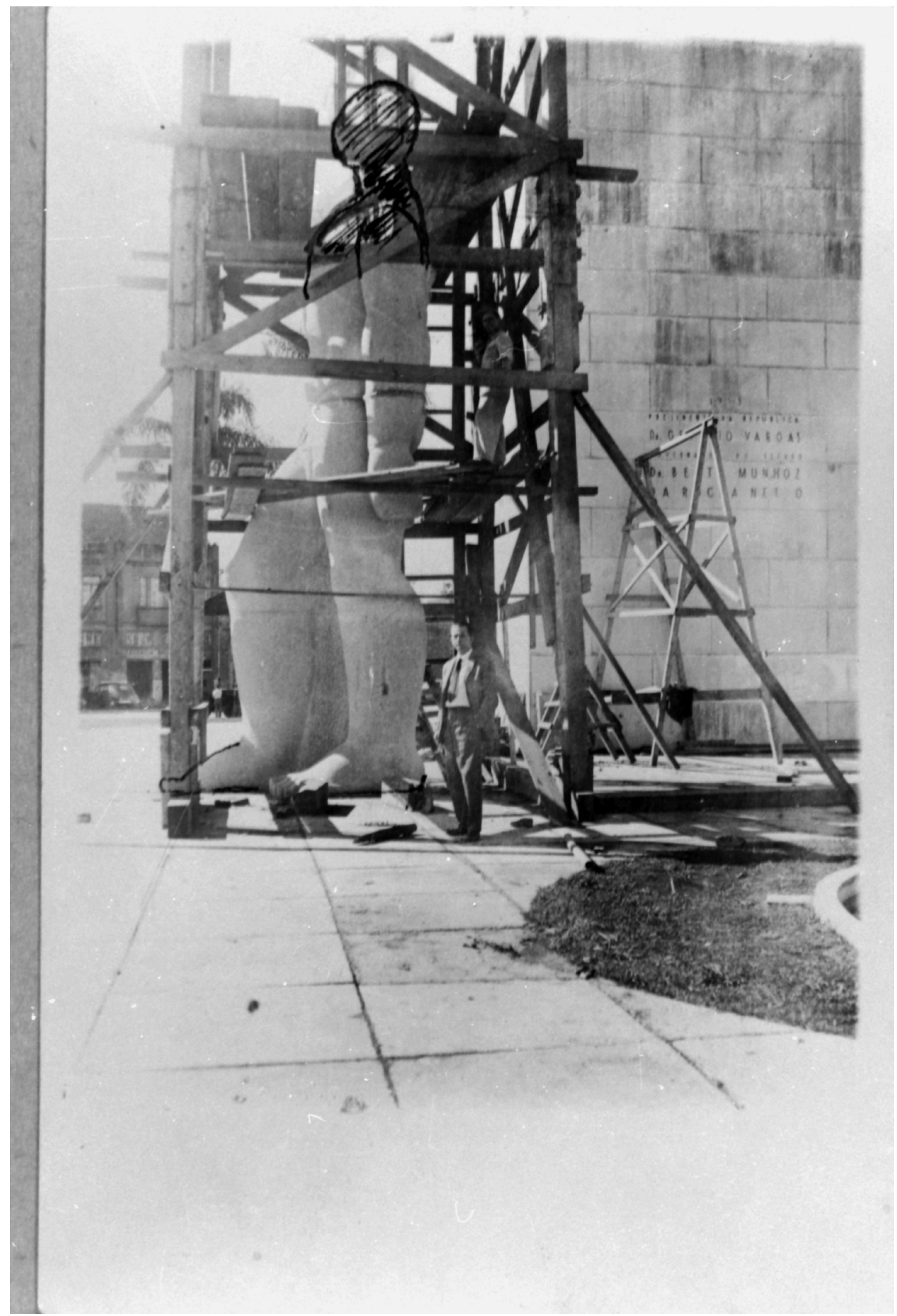

Figura 7 - A estátua sem cabeça. Fonte: Fundação Cultural de Curitiba, Fundo Erbo Stenzel, pasta "A Praça 19 de Dezembro na obra de Erbo Stenzel". 
Entre as fotos recebidas por Stenzel não há nenhuma do último bloco de granito. Uma imagem curiosa guardada pelo escultor junto à correspondência, todavia, revela certa expectativa durante a instalação da estátua. Stenzel posa diante da figura envolta em andaimes, faltando-lhe a quarta e última peça, da cabeça. À caneta, foi desenhada, possivelmente por Stenzel, a silhueta faltante, como que para imaginar o resultado final. É um desenho simples, sem feições, como os primeiros modelos trocados entre os escultores (figura 7). A apreensão transmitida pela imagem antecipa as reações que se seguiram a sua instalação, quando foram revelados traços bem diferentes daqueles impressos aos modelos de argila (figura 8).

Outra obra destinada à praça do Centro Cívico causou reação imediata devido a seus traços, mas, em vez de sofrer resistência dos modernos, foi banida do complexo pela opinião dos conservadores de Curitiba. A Cozzo, conforme mencionado acima, fora também encomendada pelo governo uma estátua da Justiça, projetada para a área em frente ao Tribunal do Júri. Assim como o homem, foi executada por Cozzo no Rio e, embora não haja na correspondência qualquer referência a ela, muitos relatos atribuem sua concepção a Stenzel. ${ }^{137}$ Tratava-se de uma mulher reclinada, nua e de formas sensuais, sem qualquer das marcas típicas da alegoria da justiça, como balança e venda. Seria instalada sobre um pedestal em bronze, que não foi construído. Um "movimento liderado por senhoras e que também teve apoio do clero" teria feito campanha contra sua exposição. ${ }^{138}$ Opuseram-se também, na percepção de Stenzel, "desembargadores e juízes que se manifestaram contrários à representação moderna da Justiça". 139 Stenzel, portanto, interpretou que sua ideia fora avançada demais para o contexto curitibano. Acabou escondida no jardim dos fundos do palácio do Executivo estadual e lá permaneceu por quase 20 anos. Nos anos 1970, foi transferida para o monumento do centenário, tendo sido instalada ao lado do homem de granito - e, juntos, passariam a ser conhecidos como a Mulher Nua e o Homem Nu.

Contrariado, Munhoz da Rocha teria se referido à polêmica, anos depois, como uma "burrice enciclopédica", 140 o que dá ideia das marcas deixadas no interior da elite pela tortuosa introdução do modernismo no Paraná. $\bigcirc$ vai e vem das duas estátuas e o papel dos agentes envolvidos mostra como o problema era complexo. governador bancou os modernos contra forte resistência, mas não abriu mão de tentar imprimir um sentido regional ao progresso e à modernização de seu estado periférico. Stenzel e Cozzo, escultores acadêmicos distanciados da vanguarda artística, esforçaram-se para ser contemporâneos e, ao orientarem suas escolhas por algumas novidades modernas, produziram obras que se chocaram com as expectativas da sociedade paranaense. $\bigcirc$ adolescente representando o Paraná e a justiça reclinada e nua materializaram a tentativa, por artistas "acadêmicos", de adotar o modernismo
137. O próprio escultor o sugere, em entrevista: "[...] O homem, que a princípio eu projetara inclinado para a frente, dando a impressão de que estava correndo, e a mulher, que representaria a Justiça, fugindo dos padrões normais, isto é, sem venda nos olhos, balança ou longo vestido". O criador fala... (1972, p. 3). Outras fontes assumem que a estátua foi "encomendada aos escultores Erbo Stenzel e Humberto Cozzo". Prefeitura Municipal de Curitiba (1988, p. 17). Mas um pedido de dispensa de licitação enviado pelo chefe da Ceoc ao governador em 1954 menciona a contratação apenas de Cozzo para a "execução da estátua monumental a ser colocada no Centro Cívico, em frente ao edifício em construção do Tribunal do Júri”. Cf. Pereira (1954).

138. Mulher de Pedra... (1972, p. 8).

139. Gonçalves (2006, p. 162)

140. Ibid. 
141. Cf. Presente de natal... (1958).

142. Um dos acadêmicos que melhor percebeu a persistência e a evolução histórica do signo racial da "diferença" entre os intelectuais do Paraná foi Márcio de Oliveira (2007).

143. Carta de Humberto Cozzo a Erbo Stenzel, 26 de outubro de 1953. Cf. Cozzo [s. d.]. como estilo, mais que como resultado de sua vinculação ao movimento moderno e seus debates. Em certo sentido, tratou-se de uma ousadia - tanto pelas escolhas estéticas quanto por ter aceito o desafio de produzir um monumento atravessado por fortes intenções e expectativas - que custaria muito desgosto a Stenzel, a ponto de ele afirmar, já em 1958: "não sou responsável por isto". ${ }^{141}$

\section{"O MONSTRO NO TRIBUNAL POPULAR"}

grupo de Munhoz da Rocha havia conseguido importar a arquitetura da escola carioca e impor a uma fração reticente da elite local o moderno como linguagem do progresso, mas sofreu reveses quando passou a questionar a brasilidade centrípeta formulada no Rio - quando buscou imprimir, em obras impregnadas de sentido nacional, uma narrativa regionalista. A estátua do Paraná jovem tomando a frente dos demais estados foi banida do complexo do Centro Cívico e o modo como o estado foi finalmente representado numa figura humana causaria revolta entre os antimodernistas (figura 8). Em um ponto, porém, a reticência da fração da elite simpática aos modernos convergiu com a revolta de sua fração reacionária: para ambos, era inegociável a branquidade como marca de diferença regional. ${ }^{142}$ As reações específicas desses grupos sugerem que, cada um a seu modo, não admitiriam a diluição do paranaense no povo brasileiro forjado pelos modernos. $\bigcirc$ duplo recuo diante da modernidade brasileira do pós-guerra levaria os paranaenses a um impasse: como ser moderno sem ser, antes, brasileiro?

Em outubro de 1953, Cozzo incluiu em sua carta um alerta a Stenzel: "[n]ão ligues muito às críticas que possam surgir, pois essas serão inevitáveis de qualquer modo. Não é possível contentar a todos 100\%". "143 Àquela altura, era claro que o monumento não seria entregue a tempo, mas as críticas que começavam a surgir talvez já se voltassem para aspectos estéticos ou de concepção. É provável que partissem de dentro do governo, a cujos membros Stenzel mostrava periodicamente as fotografias recebidas do Rio. De fato, é possível que os membros agigantados da estátua causassem desconforto, desde cedo, no círculo próximo ao governador. De qualquer modo, a imprensa governista apressou-se para enquadrar o monumento sob uma visão positiva. Em 29 de março de 1955, aniversário de Curitiba, saía o primeiro número do novo jornal governista Diário do Paraná. $\bigcirc$ suplemento comemorativo estampava na capa uma das primeiras aparições do gigante, ao lado do obelisco e do painel de Stenzel, sugerindo que o conjunto já era a obra de arte mais impressionante da cidade. Nas páginas internas, uma foto, tirada ao nível do chão, destacava o aspecto 
monumental da estátua, já montada na praça. Numa interpretação afinada com a intenção original do governador, a estátua era considerada "símbolo de uma época", expressão "hercúlea do Paraná atual, uma das grandes potências econômicas da nação brasileira". Ao mesmo tempo, torná-la compreensível para setores menos ufanos exigia adotar enquadramento mais moderno e popular, descrevendo-a como a "estátua gigante de um trabalhador". ${ }^{144}$ A perspectiva, no entanto, não era unânime em Curitiba.

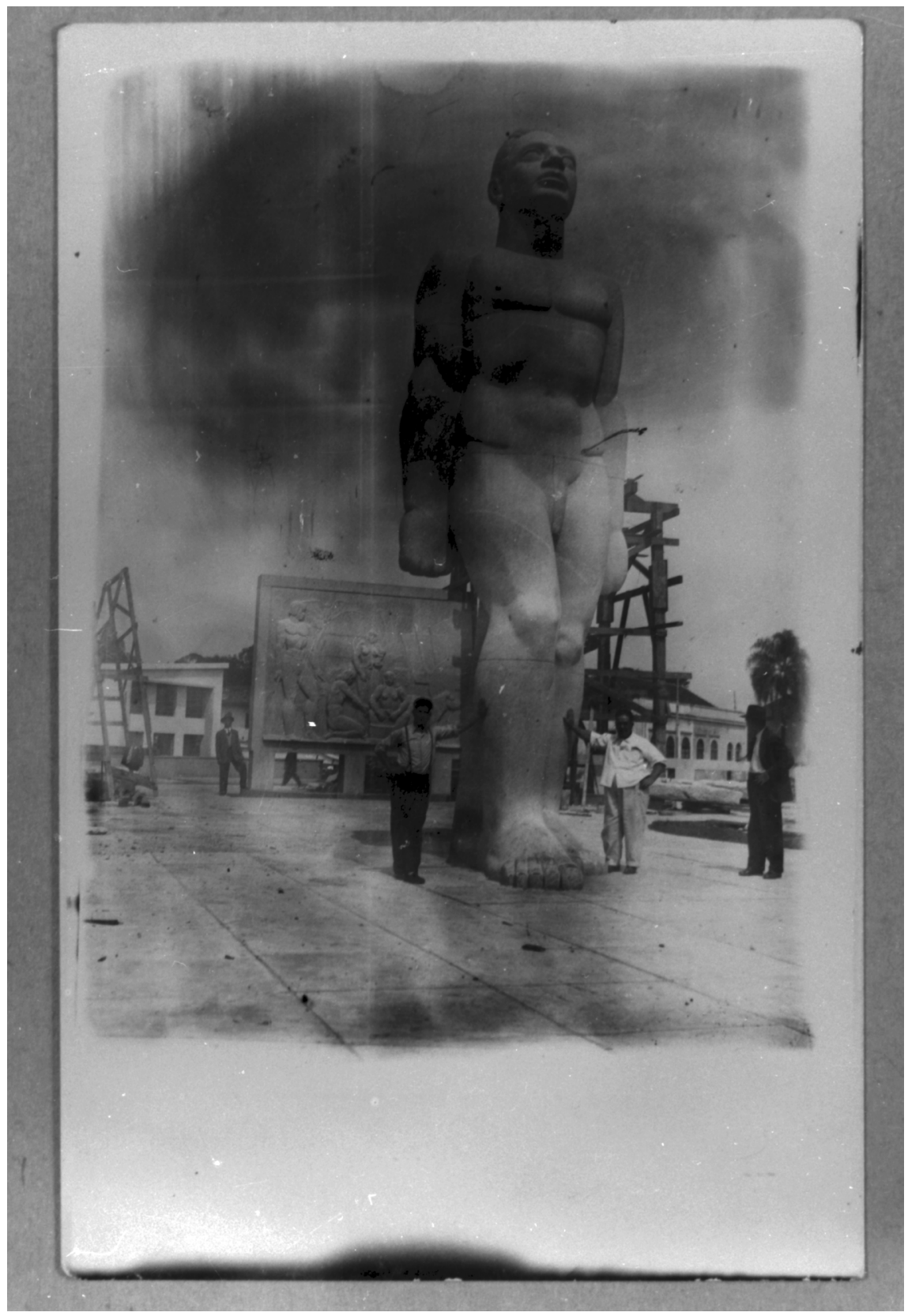

144. Perpetuada em bronze... (1955, p. 3).
Figura 8 - Stenzel, a estátua e Cozzo. Fonte: "Instalação na Praça Dezenove de Dezembro da estatua do Homem Nu, de autoria dos escultores Erbo Stenzel e Humberto Cozzo". Acervo Casa da Memória, Diretoria do Patrimônio Cultural, Fundação Cultural de Curitiba, Coleção Erbo Stenzel (ref.: $\mathrm{SN}$, 6808). 1 fotografia, $\mathrm{p} / \mathrm{b}$. 
145. O monumento da... (1955, p. 3).

146. Ariel (15 jun. 1955, p. 8).

147. Pode ter sido a história do "homem brasileiro" recusado por Capanema em 1937 ou a história do "Monumento ao Trabalhador Brasileiro", destinada à sede do Ministério do Trabalho, no Rio. Em sua inauguração, em 1950, o presidente Eurico Gaspar Dutra teria soltado um "não gostei". Segundo críticos na imprensa, Celso Antônio teria imaginado "o trabalhador brasileiro um homem atarracado, barrigudo e mal ajeitado e com o peito pouco varonil. Ainda por cima vestiu-o com uma tanga e cruzou-lhe os braços". A estátua foi retirada, mudou de lugar várias vezes e nos anos 1970 acabou instalada em Niterói, cf. Mendonça (2009).

148. Ariel (21 jun. 1955, p. $8)$.
Prevaleceu a visão negativa dos jornais de oposição. Ao noticiar a entrega do "monumento da Praça 19 de Dezembro, que tanta curiosidade e comentários despertou", O Dia elogiava o "mural em azulejo com desenhos de Poty e os baixo relevos [sic] em granito de Erbo Stenzel", mas tripudiava sobre a "estátua monstruosa ali erigida e o ridículo obelisco". 145 No mesmo número, algumas páginas adiante, o colunista de pseudônimo Ariel iniciava uma campanha contra a estátua:

não existirá uma autoridade de coragem que mande retirar quanto antes aquele monstro de pedra enxundioso, reumático, indecente e horrível planejado por um escultor que já teve mais de um monumento seu PAGO MAS ERRADICADO DO LOCAL ONDE DEVIA FICAR!

Aqui precisamos urgentemente de providência idêntica.

Paguem-no. Mas o joguem no lixo, se for possível isso.

Lá é que não pode continuar para bem da estética e do próprio conjunto monumental construído.

O sr. Cozzo tem o senso artístico deformado pela sua tendência à elefantíase $[\ldots]^{146}$

Estava claro para Ariel que o único responsável pelo gigante era o forasteiro Cozzo e que as obras dos artistas locais, ao contrário - "obras primas do talento paranaense" -, mereciam toda admiração, a ponto de o gigante ameaçar 0 "conjunto monumental". A separação entre artistas paranaenses e o forasteiro, ao gosto do paranismo tão criticado pelos modernos de Curitiba, seria constante ao longo da campanha de Ariel. Um dos aspectos desse modo de enxergar as divisões artísticas foi a confusão feita pelo colunista ao tomar Cozzo por Celso Antônio, quem de fato tivera "mais de um monumento seu pago, mas erradicado". A confusão é interessante porque sinaliza que, ao aproximar-se da estética moderna - mesmo com pouca destreza e convicção -, Cozzo atiçou ao mesmo tempo a resistência paranista àquilo que vinha de fora e o reacionarismo antimoderno. Mas como Ariel chegou a conhecer as desventuras de Celso Antônio no Rio? Ao que parece, Stenzel, ao contrário do que the recomendara Cozzo, sentiu o golpe das críticas e atuou pessoalmente para se eximir da responsabilidade pelo gigante. Antes de Ariel lançar sua campanha, o escultor teria the contado sobre os tais "monumentos erradicados". ${ }^{147}$ Assim, alguns dias depois, ao reconhecer ter-se confundido, Ariel escreveu: "[f]oi mesmo outro o escultor me citado por Stenzel". ${ }^{48}$

Ariel pode ter buscado seu codinome na peça A Tempestade. O Ariel de Shakespeare, embora fosse "espírito delicado demais" para coisas "terrenas e repugnantes" (ato I, cena 2), era ardiloso e cheio de truques. Aos poucos, seu xará 
de Curitiba lançou mão de todos os recursos capazes de angariar apoio entre parcelas da sociedade curitibana. No dia seguinte à inauguração, voltou à carga e chamou o gigante de "TARADÃO DE PEDRA". 149 Mais um dia e apontou sua mira para as senhoras. Reproduziu o relato de uma "senhora da alta sociedade e de nossas relações" que, "passando com netinhas pela praça 19 de Dezembro, uma delas the perguntou: - Vovó, por que aquele homem não se veste?"150 Quando lembrou-se de uma escola em construção nas proximidades da praça, escreveu que "manda a decência que se evite aos olhares da infância a exibição daquele tarado [...], defendido como uma Interpretação do Homem do Paraná!" 151

A revolta com a tal "interpretação" sugere que parte da "curiosidade e comentários" despertados pelo monumento até sua entrega oficial tinha a ver com a "cara" que o Paraná teria na estátua - isto é, esperava-se uma representação minimamente literal. Ao questionar suas feições, Ariel apelava para essa expectativa, atingindo mais um público em potencial. Qualquer interpretação, para ele, deveria materializar-se numa figura inequivocamente branca. Assim, o "taradão" - no mínimo, racialmente ambíguo -, além de ofender a "moral pública", constituiria também "um atentado à nossa etnologia". ${ }^{152}$ Para "escândalo dos olhares de nossa gente", escreveu Ariel, "ele não materializa uma interpretação de nosso homem que é esbelto e branco". 153 Até mesmo a única opinião circunstanciada recolhida pela campanha de Ariel repisaria essa questão. fotógrafo e cineasta João Baptista Groff, "partidário da liberdade do artista [...], embora condenando a criação como representativa do homem do Paraná, julgou que para outro fim ele a justificaria". 154 Entre argumentos moralistas, racistas e outros que apenas consideravam feia aquela imitação pouco convicta do estilo moderno, uma parte influente da elite curitibana cerrou fileiras com Ariel.

Em duas semanas, o colunista podia ostentar seu apoio. Conquistara o editorial de $\bigcirc$ Dia, que expôs na capa, em letras grandes, "o monstro diante do júri popular". ${ }^{155}$ De popular, nas opiniões apresentadas, não havia nada, como reconheceria o colunista Fradique Mendes, mais um apoiador da campanha ("Folgo em constatar que pessoas do mais alto senso crítico condenaram aquela monstruosidade"|. ${ }^{156} \bigcirc$ editorial trazia o resultado de "um inquérito relâmpago entre elementos de nossas camadas sociais", isto é, professores universitários, artistas, um ex-prefeito e o presidente do Clube Curitibano, o mais tradicional da cidade. Qualificavam o monumento de "obsceno" e "uma monstruosidade", entre outros. Destaca-se a opinião de Fernando Corrêa de Azevedo. Em janeiro de 1949, o diretor da Escola de Música e Belas Artes do Paraná defendera o projeto de Rubens Meister para o teatro Guaíra. Seu artigo teria sido decisivo porque influenciou o governador
149. Id., 16 jun. 1955 , p. 8. 150. Id., 17 jun. 1955 , p. 8. 151. Id., 22 jun. 1955 , p. 8. 152. Id., 16 jun. 1955 , p. 8. 153. Id., 26 jun. 1955 , p. 8. 154. Cf. O monstro no... (1955).

155. Ibid.

156. Mendes (1955, p. 3). 
157. Dudeque (2001, p. 415).

158. Cf. O monstro no... (1955).

159. Ariel (21 jun. 1955, p. 8).

160. Cf. Oliveira (2007).
Munhoz da Rocha a encampar a introdução da arquitetura moderna em Curitiba por meio do programa de obras públicas. ${ }^{157}$ Agora, sob a campanha de Ariel, atacava o gigante sumariamente: "um horror!" Era um paranaense simpático aos modernos que recuava diante da estátua trazida do Rio. Talvez a considerasse um pastiche de moderno, o que acrescentaria alguma complexidade ao grupo que passou a se opor à estátua. A ironia do "tribunal popular" contra o gigante é encontrar Azevedo, defensor da arquitetura moderna, de braços dados com David Carneiro, um reacionário. A opinião de Carneiro, aquele que criticou acidamente os projetos modernos para o teatro e o centro administrativo, era a mais forte: "aquilo não representa coisa nenhuma. Não tem expressão. Não significa coisa alguma, e muito menos o adolescente, ou o homem deste Paraná dolicocéfalo, loiro e belo. Um simples bloco de granito nos representaria melhor". ${ }^{158}$ Em suma, a visão do Paraná diluindo-se num Brasil moderno, frequentemente representado como não branco, conseguiu reunir os dois pólos da elite.

Os paranaenses encontravam-se num impasse diante da incorporação de sua região periférica à modernidade nacional. Como ser moderno sem se diluir na modernidade brasileira do pós-guerra - sem deixar de ser branco? Num dos textos mais desenvoltos da campanha, uma tirada de Ariel evidencia aguda consciência da interseção entre os aspectos regional e racial do problema: "[e]stava cego esse ARTIXTA (artixta com xiz, senhores linotipista e revisores) [...] Aquele tipo de Frankenstein não evoca o paranaense esbelto, com maior número de loiros que morenos". 159 "ARTIXTA" obviamente associava Cozzo ao sotaque carioca. Pouco importava se Cozzo era, na verdade, paulista, porque, para Ariel e seus leitores, o oposto da periferia branca só podia ser a capital mestiça. No impasse que tomou a elite paranaense em torno aos eventos do centenário, a única modernidade aceitável seria uma modernidade embranquecida.

Uma nova narrativa regional emergiria e viria a se consolidar nos anos seguintes, respondendo a esse impasse. Uma narrativa capaz de conciliar aspectos do movimento moderno, tais como a incorporação do povo e do trabalhador à representação da região, com o sentimento de branquidade que levava muitos paranaenses de elite - mas não apenas - a imaginarem sua região em oposição ao Brasil, tal como definido a partir de São Paulo e do Rio de Janeiro. Nessa nova narrativa, os imigrantes europeus teriam papel destacado. ${ }^{160}$ Mas sua emergência escapa ao objetivo deste artigo, que se limitou a explorar a busca da modernidade por meio da arquitetura, os recuos diante de uma modernidade de sentido explicitamente nacional e o aspecto racial desse recuo, mostrando que a branquidade dos paranaenses era um valor inegociável para grande parte de sua elite. 
Entre os polos que o compreendiam como "trabalhador" ou como "monstrengo" não branco, o impasse de que o Homem Nu fora fruto prolongou-se para além do centenário. Em 1958, o "Paraná adolescente" e a "Justiça" transformavam-se, na imprensa, em "casal de macacos". $\bigcirc$ "macaco do centenário", em especial, teria sido feito pela opinião pública "objeto de [...] pilhérias e de seu cordial desprezo". ${ }^{161}$ Nos anos 1970, a memória da cidade os lembraria já como "Homem Nu" e "Mulher de Pedra", 162 e, em meados dos anos 1990, uma monografia inédita sobre os monumentos da cidade voltava a reforçar a perspectiva antiga de seu idealizador: "O Homem Livre de Todas as Peias" - seria o título da escultura -, "integrante do folclore da cidade, [simbolizaria] o Paraná, destemido, enfrentando o futuro, buscando novos horizontes". ${ }^{163}$ Mas a perspectiva racista deixara marcas profundas: em outro documento da prefeitura, mais antigo, que inventariava as praças de Curitiba, o "monumento em pedra" era referenciado simplesmente como "escravo", 164 numa referência ambígua que poderia remeter tanto a sua "cor" quanto à emancipação política do estado do Paraná. A partir dos anos 2000, diversas pesquisas sobre o monumento /citadas ao longo deste artigol passaram a questionar a incompreensão e o conservadorismo que fundamentaram sua rejeição, estimulando um processo de ressignificação pública das estátuas, que se recriaram como "lugares de memória". ${ }^{165}$ Tendo permanecido no centro de Curitiba como uma dissonância no discurso da branquidade, a Mulher Nua e o Homem Nu são hoje reivindicados como símbolos da cidade não branca e não conformista historicamente silenciada.
161. Cf. Presente de natal... (1958).

162. Mulher de Pedra... (1972, p. 8).

163. Cordeiro ([s. d.], p. 14).

164. Praça 19 de Dezembro ([s. d.]).

165. Cf. Bahls (2009). 


\section{REFERÊNCIAS}

FONTES MANUSCRITAS

COZZO, Humberto. [Correspondência]. Destinatário: Erbo Stenzel. [s. l.; s. d.]. Fundação Cultural de Curitiba, Fundo Erbo Stenzel, pasta A Praça 19 de Dezembro na obra de Erbo Stenzel.

MARX, Roberto Burle. Proposta a Elato Silva. Rio de Janeiro, 4 ago. 1953. Arquivo Público do Paraná, fundo Comissão de Comemorações do Centenário do Estado do Paraná, caixa 24/07/69/46.

PEREIRA, Ivo Arzua. [Correspondência]. Destinatário: Bento Munhoz da Rocha Neto, [s. l.], 13 ago. 1954. Arquivo Público do Paraná, fundo Comissão de Comemorações do Centenário do Estado do Paraná, caixa 24/07/67/01.

PEREIRA, Ivo Arzua. [Correspondência]. Destinatário: Bento Munhoz da Rocha Neto, [ $s$. l.], 20 jan. 1955a. Arquivo Público do Paraná, fundo Comissão de Comemorações do Centenário do Estado do Paraná, caixa 24/07/68/01.

PEREIRA, Ivo Arzua. [Correspondência]. Destinatário: Antonio Anibelli, [s. l.], 30 abr. 1955b (anexo). Arquivo Público do Paraná, fundo Comissão de Comemorações do Centenário do Estado do Paraná, caixa 23/41/08/08.

PEREIRA, Ivo Arzua. [Correspondência]. Destinatário: Bento Munhoz da Rocha Neto, [s. l.], 12 maio 1955c. Arquivo Público do Paraná, fundo Comissão de Comemorações do Centenário do Estado do Paraná, caixa 24/07/68/11.

PRAÇA 19 de Dezembro. [s. d.]. Biblioteca Casa da Memória, Fundação Cultural de Curitiba, pasta Praças "D”.

SILVA, Elato. Ofícios ao governador Bento Munhoz da Rocha Neto, [s. l.], 26 dez. 1952 e 9 mar. 1953. Arquivo Público do Paraná, fundo Comissão de Comemorações do Centenário do Estado do Paraná, caixa 24/07/67/01.

TERMO de contrato de locação de serviços entre o estado do Paraná e o engenheiro civil Elato Silva. [s. l.; s. d.]. Arquivo Público do Paraná, fundo Comissão de Comemorações do Centenário do Estado do Paraná, caixa 23/40/01/03. 


\section{FONTES ICONOGRÁFICAS}

A ESTÁTUA sem cabeça. [s. d.]. 1. Fotografia. Acervo da Fundação Cultural de Curitiba, Fundo Erbo Stenzel, pasta A Praça 19 de Dezembro na obra de Erbo Stenzel.

COZZO, Humberto. Maquete. [s. d.]. 1. Fotografia. Acervo da Fundação Cultural de Curitiba, Fundo Erbo Stenzel, pasta A Praça 19 de Dezembro na obra de Erbo Stenzel.

STENZEL, a estátua e Cozzo. [s. d.]. 1 fotografia, p/b. Instalação na Praça Dezenove de Dezembro da estatua do Homem $\mathrm{Nu}$, de autoria dos escultores Erbo Stenzel e Humberto Cozzo. Acervo Casa da Memória, Diretoria do Patrimônio Cultural, Fundação Cultural de Curitiba, Coleção Erbo Stenzel (ref.: SN, 6808).

STENZEL, Erbo. Torso de Trabalhador. 1941. 1. Escultura. Acervo do Museu de Arte do Paraná. Erbo Stenzel, 1911 - 1989: escultura, desenho, gravura. Exposição realizada por ocasião do décimo quinto aniversário de falecimento do artista, Curitiba, 6 de julho a 25 de agosto de 1995 [panfleto].

STENZEL, Erbo; COZZO, Humberto. O modelo de argila, "branco". [s. d.]. 1 fotografia, p/b. Modelos em barro em escalas diferentes da estátua do Homem $\mathrm{Nu}$, dos escultores Erbo Stenzel e Humberto Cozzo. Acervo Casa da Memória, Diretoria do Patrimônio Cultural, Fundação Cultural de Curitiba, Coleção Erbo Stenzel (ref.: SN, 6967).

FONTES IMPRESSAS

ARIEL. Tópicos da Cidade. O Dia, Curitiba, jun.-jul. 1955.

CARNEIRO, David. O conjunto arquitetônico do Centro Cívico. O Dia, $1^{\circ}$ maio 1952, p. 3.

CENTRE CIVIQUE. L'Architecture d'Aujourd'bui, n. 42, 1952.

C.E.O.C., uma sigla que passará à história do progresso paranaense. O Estado do Paraná, Curitiba, 19 dez. 1953, p. 26.

COMISSÃO de Comemorações do Centenário do Paraná. O Estado do Paraná, 19 dez. 1953 (Edição especial). 
CORDEIRO, João Jorge. Os monumentos da cidade de Curitiba. [s. d.], p. 14. Biblioteca da Casa da Memória, Fundação Cultural de Curitiba.

MENDES, Fradique. Instantâneos. O Dia, 7 jul. 1955, p. 3.

MENSAGEM apresentada à Assembleia Legislativa do Estado por ocasião da $1^{\text {a }}$ sessão ordinária da segunda legislatura pelo senhor Bento Munhoz da Rocha Neto, governador do Paraná. Curitiba, Paraná, 1951, p. 115.

MENSAGEM apresentada à Assembleia Legislativa do Estado por ocasião da $2^{\text {a }}$ sessão ordinária da segunda legislatura pelo senhor Bento Munhoz da Rocha Neto, governador do Paraná. Curitiba, Paraná, 1952, p. 193.

MILLARCH, Aramis. Meister, o homem do teatro Guaíra. O Estado do Paraná, 25 out. 1990, p. 24.

MONUMENTO do Centenário do Paraná. Brasil Arquitetura Contemporânea, n. 1, ago.-set. 1953.

MULHER de Pedra já mora junto ao "Homem Nu". Diário do Paraná, Curitiba, 31 ago. 1972 , p. 8.

O CRIADOR fala sobre a sua obra. A mulher nua ainda não está no lugar planejado. Diário do Paraná, 4 set. 1972 , p. 3.

O MONSTRO no Tribunal Popular!”. O Dia, Curitiba, 3 jul. 1955.

O MONUMENTAL Centro Cívico de Curitiba, Ilustração Brasileira, ano XLIV, n. 224, dez. 1953.

O MONUMENTO da Praça 19 e sua entrega”. O Dia, Curitiba, 15 jun. 1955, p. 3.

OURO PRETO, Carlos Celso de. Introduction. L'Architecture d'Aujourd'hui, n. 42, 1952, p. 1.

PARANÁ. Decreto no 1.084 de 11 de maio de 1951. Diário Oficial do Estado do Paraná, Curitiba, ano XXXIX, $\mathrm{n}^{\circ}$ 56, 11 maio 1951, p. 1.

PARANÁ. Lei n ${ }^{\circ} 674$ de 29 de agosto de 1951. Diário Oficial do Estado do Paraná, Curitiba, ano XXXIX, $\mathrm{n}^{\circ} 145,30$ ago. 1951, p. 1.

PARANÁ e Santa Catarina. O Cruzeiro, 21 jun. 1952. 
PERPETUADA em bronze e granito a glória dos homens do passado. Diário do Paraná, Curitiba, 29 de março de 1955 (Suplemento Comemorativo do Aniversário da Cidade).

PREFEITURA MUNICIPAL DE CURITIBA. Boletim PMC, ano 2, n. 12, nov.-dez. 1943. Curitiba: Empresa Gráfica Paranaense. Disponível em: <https://bit.ly/2T6oWFr>. Acesso em: 7 mar. 2019.

PREFEITURA MUNICIPAL DE CURITIBA. Boletim Informativo da Casa Romário Martins, Curitiba, v. 15, n. 82, agosto de 1988, p. 17.

PRESENTE de natal para o macaco de pedra da Praça 19 de Dezembro", Diário do Paraná, Curitiba, 23 dez. 1958.

LIVROS, ARTIGOS E TESES

BAHLS, Aparecida Vaz da Silva. Símbolos e monumentos: as comemorações de emancipação política do Paraná nos logradouros de Curitiba. Publicatio UEPG: Ciências Humanas, Ciências Sociais Aplicadas, Linguística, Letras e Artes, Ponta Grossa, v. 14, n. 1, p. 7-20, jun 2006.

BATISTEllA, Alessandro. O Partido Trabalhista Brasileiro no Paraná. Topoi, Rio de Janeiro, v. 17, n. 32, p. 257-286, jan.-jun. 2016.

BATISTELLA, Alessandro. A campanha oposicionista ao governador paranaense Bento Munhoz da Rocha Neto (1951-1955) por meio da caricatura política. In: XXIX Simpósio Nacional de História, Brasília, Brasília: UnB, 2017.

BEGA, Maria Tarcisa Silva. Letras e política no Paraná: simbolistas e anticlericais na República Velha. Curitiba: Editora UFPR, 2013.

CAmARgo, Geraldo Leão Veiga de. Paranismo: arte, ideologia e relações sociais no Paraná. 2007. Tese (Doutorado em História) - Setor de Ciências Humanas, Universidade Federal do Paraná, Curitiba, 2007.

CAVALCANTI, Lauro. Moderno e brasileiro: a criação de uma nova linguagem na arquitetura (1930-1960). Rio de Janeiro: Zahar, 2006.

CERCHIARO, Marina Mazze. Esculpindo para o Ministério: arte e política no Estado Novo. 2016a. Tese (Mestrado em Filosofia) - Instituto de Estudos Brasileiros, Universidade de São Paulo, São Paulo, 2016a. 
CERCHIARO, Marina Mazze. Esculpindo o ideal de "homem novo": discursos sobre raça, gênero e nação no Estado Novo. In: $30^{a}$ Reunião Brasileira de Antropologia, João Pessoa, João Pessoa: UFPB, 2016b.

CHUVA, Márcia. Fundando a nação: a representação de um Brasil barroco, moderno e civilizado. Topoi, Rio de Janeiro, v. 4, n. 7, jul.-dez. 2003, p. 313-333.

COMISSÃO de Comemorações do Centenário do Paraná. International Coffee Exhibition - Exposição Internacional do Café. Curitiba: Impressora Paranaense, [s. d.].

DECKKER, Zilah Quezado. Brazil built: the architecture of the modern movement in Brazil. Londres; Nova York: Spon Press, 2001.

DUDEQUE, Irã Taborda. Espirais de madeira: uma história da arquitetura de Curitiba. São Paulo: Studio Nobel; FAPESP, 2001.

FISCHER, Brodwyn. A Poverty of Rights: Citizenship and inequality in twentieth-century Rio de Janeiro. Stanford, CA: Stanford University, 2008.

GALANI, Luan. Histórias da Biblioteca Pública que os livros não contam. Gazeta do Povo, Caderno Haus, Curitiba, 4 ago. 2015.

GNOATO, Luís Salvador Petrucci. Introdução do ideário modernista na arquitetura de Curitiba (1930-1965). 1997. Dissertação (Mestrado em Arquitetura e Urbanismo) - Faculdade de Arquitetura e Urbanismo, Universidade de São Paulo, São Paulo, 1997.

GNOATO, Luís Salvador Petrucci. Racionalismo e rigor construtivo. Revista Arquitetura e Urbanismo, n. 160, jul. 2007. Disponível em: <https://bit.ly/2F5lhDc>. Acesso em: 7 mar. 2019.

GONÇALVES, Josilena Maria Zanello. Integração das artes no Paraná (1950-1970): a conquista do espaço público. 2006. Tese (Doutorado em Arquitetura e Urbanismo) - Faculdade de Arquitetura e Urbanismo, Universidade de São Paulo, São Paulo, 2006.

GUIMARÃES, Antonio Sérgio Alfredo. Democracia racial: o ideal, o pacto e o mito. Novos Estudos, n. 61, nov. 2001, p. 147-162.

GUIMARÃES, Antonio Sérgio Alfredo. Raça, cor, cor da pele e etnia. Cadernos de Campo, São Paulo, v. 20, jan.-dez. 2011.

IPARDES. O Paraná reinventado: política e governo. Curitiba: [s. n.], 1989. 
MACHADO, Daiane Vaiz. O percurso intelectual de uma personalidade curitibana: David Carneiro. 2012. Dissertação (Mestrado em História) - Setor de Ciências Humanas, Universidade Federal do Paraná, Curitiba, 2012.

MENDONÇA, Paulo Knauss. Arte pública e direito à cidade: o encontro da arte com as favelas do Rio de Janeiro contemporâneo. Tempo \& Argumento, Florianópolis, v. 1, n. 1, 2009.

MUELLER, Oscar. Centro Cívico de Curitiba: um espaço identitário. 2006. Dissertação (Mestrado em Arquitetura) - Faculdade de Arquitetura, Universidade Federal do Rio Grande do Sul, Porto Alegre, 2006.

NOGUEIRA, Oracy. Preconceito racial de marca e preconceito racial de origem: sugestão de um quadro de referência para a interpretação do material sobre relações raciais no Brasil. Tempo Social, São Paulo, v. 19, n. 1, 2006 [1955].

OLIVEIRA, Luiz Claudio Soares de. Joaquim contra o paranismo. 2005. Dissertação (Mestrado em Estudos Literários) - Setor de Ciências Humanas, Universidade Federal do Paraná, Curitiba, 2005.

OLIVEIRA, Márcio de. Imigração e diferença em um estado do sul do Brasil: o caso do Paraná. Nuevo Mundo Novos Mundos, maio 2007. Disponível em: <https://bit.ly/2VXPDhK>. Acesso em: 7 mar. 2019.

PACHECO, Paulo Cesar Braga. A arquitetura do Grupo do Paraná 1957-1980. 2010. Tese (Doutorado em Arquitetura) - Faculdade de Arquitetura, Universidade Federal do Rio Grande do Sul, Porto Alegre, 2010.

PADIS, Pedo Calil. O Paraná: uma visão de conjunto. Revista de Administração de Empresas, v. 11, n. 1, jan.-mar. 1971, p. 35-50.

PADIS, Pedo Calil. Formação de uma economia periférica: o caso do Paraná. São Paulo; Curitiba: HUCITEC; Secretaria da Cultura e do Esporte do Governo do Estado do Paraná, 1981.

PEREIRA, Magnus Roberto de Mello. Semeando iras rumo ao progresso: ordenamento jurídico e econômico da sociedade paranaense, 1899-1889. Curitiba: Editora UFPR, 1996.

ROMANOVSKI, Natalia. Um grupo abstrato: cultura, geração e ambições modernas na Revista Joaquim. 2014. Dissertação (Mestrado em Sociologia) - Faculdade de Filosofia, Letras e Ciências Humanas, Universidade de São Paulo, São Paulo, 2014.

ROMANOVSKI, Natalia. A consagração na escrita da história: um olhar sociológico sobre a revista Joaquim. Estudos Sociológicos, Araraquara, v. 21, n. 40, jan.-jun. 2016, p. 197-214. 
SEGAWA, Hugo. Arquiteturas no Brasil. São Paulo: Edusp, 1998.

SIMIONI, Ana Paula Cavalcanti. Modernismo brasileiro: entre a consagração e a contestação. Perspective [on-line], n. 2, 2013. Disponível em: <https://bit.ly/2PqnNtl>. Acesso em: 26 fev. 2020.

TEIXEIRA, Selma Suely. Teatro em Curitiba na década de 50: história e significação. 1992. Dissertação (Mestrado em Letras) - Setor de Ciências Humanas, Universidade Federal do Paraná, Curitiba, 1992.

WEINSTEIN, Barbara. Racializando as diferenças regionais: São Paulo X Brasil, 1932. Esboços, Florianópolis, n. 16, 2006, p. 281-303.

WEINSTEIN, Barbara. The color of modernity: São Paulo and the making of race and nation in Brazil. Durham; Londres: Duke University, 2015.

Artigo apresentado em 27/03/2019. Aprovado em $31 / 01 / 2020$.

\section{(c) BY}

All the contents of this journal, except where otherwise noted, is licensed under a Creative Commons Attribution License 